\title{
THE WATER FLOW INTO THE ENGLISH CHANNEL FROM THE SOUTH-WEST
}

\author{
By L. H. N. COOPER \\ The Plymouth Laboratory
}

(Text-figs. I-I7)

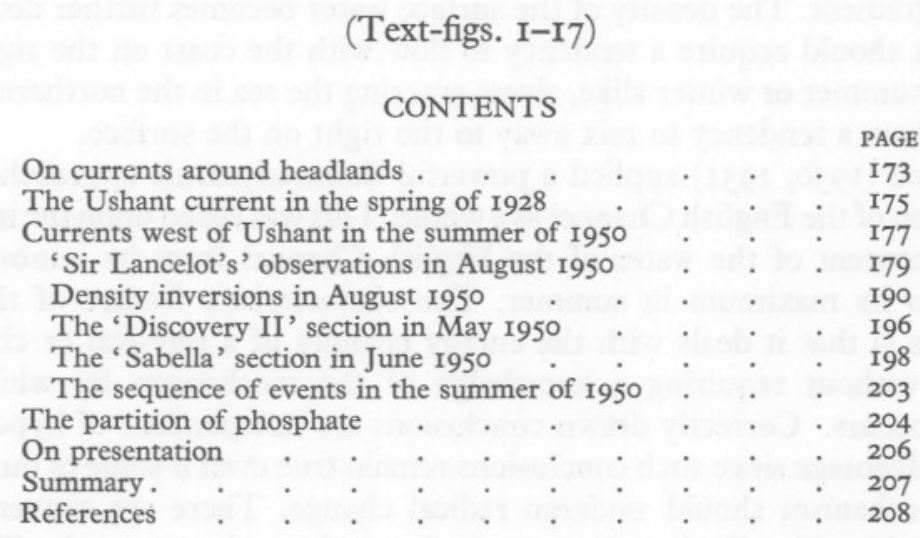

\section{ON CURRENTS AROUND HEADLANDS}

The physical oceanography of the shallow seas south-west of the British Isles is much influenced by the exchanges of waters around headlands between neighbouring areas of the sea. These are:

Bay of Biscay (south-west of Brittany)-Ushant-English Channel

English Channel-Lands End-Bristol Channel

Bristol Channel-St David's Head-St Georges Channel

St Georges Channel-Carnsore Point-Celtic Sea (south of Co. Waterford)

This paper discusses the first of these, the recruitment of water from south and west of Ushant into the English Channel. Exchanges of water around the other headlands, together with the recruitment into the English and Bristol Channels of 'western' or 'elegans' waters will be discussed in a further paper now in preparation.

Off the Island of Ushant (I. d'Ouessant) the coast falls steeply to a peneplain at about $\mathrm{I} I \mathrm{O} \mathrm{m}$. Tides are very strong and the coastline very rugged. Twenty-five miles to the south the Chaussée de Sein (The Saints shoal) projects about 15 miles to seaward and must cause much mixing in coastal water which may flow northwards along the coast of Brittany towards Ushant. Here in summer the surface layers often become cooler and the deeper layers 
warmer than at corresponding depths in the sea to the westward. The distribution of mass is then such as to encourage the north-going current round the island to flow most strongly not at the surface but at a level around 20-30 m corresponding to that of the thermocline in the sea to the westward. If no other forces were operating the current at surface and near the bottom would flow southward from the English Channel into the Bay of Biscay.

However, in summer, after wet weather, land drainage contributes to the epithalassa and only slowly to the hypothalassa by vertical mixing against a density gradient. The density of the surface water becomes further decreased so that it should acquire a tendency to flow with the coast on the right. In general, summer or winter alike, rivers entering the sea in the northern hemisphere show a tendency to mix away to the right on the surface.

Dietrich (I950, I95I) applied a powerful thermodynamic approach to the circulation of the English Channel as a whole. This was based upon the increase in heat content of the water of the English Channel from its minimum in winter to its maximum in summer. The characteristic feature of thermodynamics is that it deals with the energy changes of a physical or chemical process without requiring a knowledge of the mechanism by which the process occurs. Correctly drawn conclusions are independent of hypothesis, a great advantage since such conclusions remain true even if some of our views about mechanism should undergo radical change. There are converse and very considerable disadvantages to a thermodynamic approach. Without help from other disciplines it cannot give information about mechanism. Consequently it is essential clearly to separate Dietrich's treatment into two parts, that which is strictly thermodynamic and that which is not so.

The unassailable part of Dietrich's paper (his Abbildung 4 ) is his conclusion that an area on the southern side of the Channel from immediately northwest of Ushant towards the north of the Cherbourg peninsula has a far greater range of temperature than can be accounted for by local exchanges of heat. There must be currents which bring much heat into the area or take it away.

As so often in physics and in physical chemistry, advance is fastest when thermodynamics can be complemented by another approach using, for example, kinetics or continuity of properties. Such methods admit of accurate study of detail, but first attempts at generalization, leaning all too heavily on analogy and intuition, may appear to conflict.

West of the meridian $3^{\circ} \mathrm{W}$., the eastern limit of this study, there appears no conflict between my findings, as set out below, and the 13 figures published by Dietrich. Unfortunately those parts of Dietrich's interpretation which are not thermodynamic do not always agree well with mine. In particular, in stratified water north and west of Brittany, this investigation suggests that the residual current at depth sets to the left of that in the upper water. Hansen (I950) produced evidence with which Dietrich concurs that for tidal 
currents in similar circumstances mass transport tends towards the coast (i.e. to the right) in the bottom layers and away from it in the upper layers. ${ }^{\star}$

\section{THE USHANT CURRENT IN THE SPRING OF 1928}

Let us now consider the current around Ushant in late winter and spring following prolonged heavy rain over France. Events in 1928, already briefly discussed by Poole \& Atkins (1929, p. 318), illustrated the nature of this flow. Further information was published by the Conseil International (I929, $a, b)$.

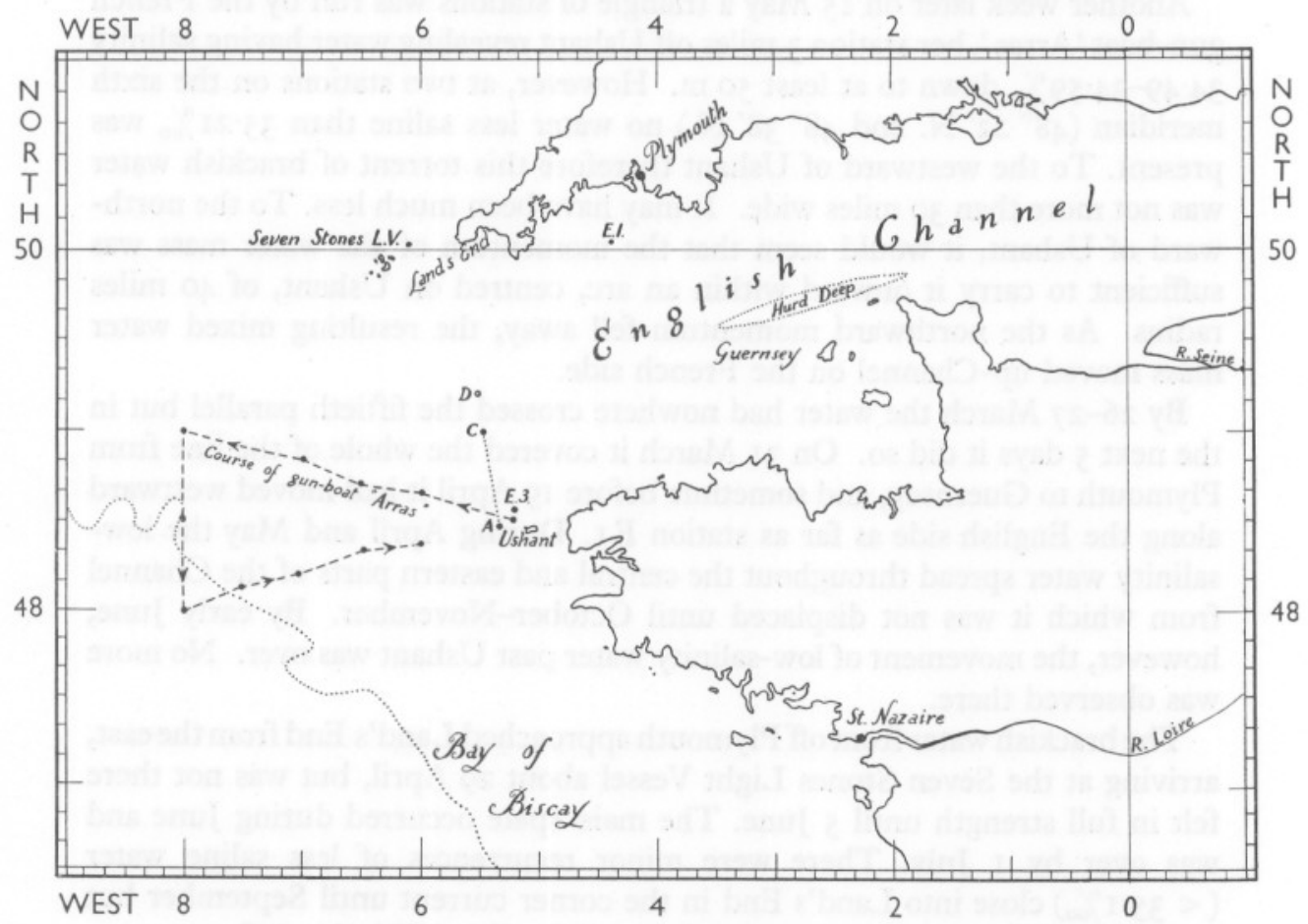

Fig. I. A chart to illustrate the spread of run-off from the Loire watershed during the spring of 1928 .

Early in that year very heavy rainfall occurred in the basin of the Loire, exceeding the normal for the 3 months January-March by $55 \%$, whereas in England it was unexceptional. The heavy run-off spread northwards from the neighbourhood of St Nazaire (Fig. I), so providing a label enabling its subsequent movement to be followed. Water of somewhat reduced salinity had begun to enter the English Channel by 22 February, the salinity at $\mathrm{E}_{3}$ being $35.01-35.09 \%$. By 24 March water of exceptionally low salinity $(34.06 \%$ )

* Of Carruthers's (1927) drift bottle results, the few that are relevant to this enquiry support the views of Dietrich and of Hansen rather than my own. 
was still present off Ushant at position $A$. In the following II days this brackish water spread out for over 30 miles north of Ushant (4 surface salinities on line $A C 34 \cdot 74-34 \cdot 85 \%$ ). It had also reached eastward along the French coast to the Hurd Deep in $3^{\circ} \mathrm{W}$.

By 5 May the stream of low-salinity water north of Ushant had widened by a further I 3 miles to include the position $D$ (five salinities between $34.4 \mathrm{I}$ and $34.88 \%$ ). On 9 May it was sampled by R.V. 'Salpa' at $\mathrm{E}_{3}$ when the uppermost $15 \mathrm{~m}$ had a salinity of $34.8 \%$.

Another week later on I5 May a triangle of stations was run by the French gun-boat 'Arras', her station 3 miles off Ushant revealing water having salinity $34 \cdot 49-34 \cdot 59 \%$ down to at least $50 \mathrm{~m}$. However, at two stations on the sixth meridian $\left(48^{\circ} 22^{\prime} \mathrm{N}\right.$. and $48^{\circ} 38^{\prime} \mathrm{N}$.) no water less saline than $35^{\circ} 2 \mathrm{I} \%$ was present. To the westward of Ushant therefore this torrent of brackish water was not more than 30 miles wide. It may have been much less. To the northward of Ushant, it would seem that the momentum of the water mass was sufficient to carry it onward within an arc, centred on Ushant, of 40 miles radius. As the northward momentum fell away, the resulting mixed water mass moved up-Channel on the French side.

By 26-27 March the water had nowhere crossed the fiftieth parallel but in the next 5 days it did so. On 3I March it covered the whole of the line from Plymouth to Guernsey, and sometime before I9 April it had moved westward along the English side as far as station Er. During April and May the lowsalinity water spread throughout the central and eastern parts of the Channel from which it was not displaced until October-November. By early June, however, the movement of low-salinity water past Ushant was over. No more was observed there.

The brackish water from off Plymouth approached Land's End from the east, arriving at the Seven Stones Light Vessel about 29 April, but was not there felt in full strength until 5 June. The main spate occurred during June and was over by I July. There were minor recurrences of less saline water $(<35.1 \%$ ) close into Land's End in the corner current until September but at the Seven Stones Light Vessel ( $50^{\circ} 04^{\prime}$ N., $6^{\circ} \mathrm{O}^{\prime}$ W.) this influence was not again detected. It is clear that the corner current around Land's End $\left(50^{\circ} 04^{\prime} \mathrm{N} ., 5^{\circ} 43^{\prime} \mathrm{W}\right.$.) was carrying a considerable volume of Loire and Seine watershed water even though the influence at the light vessel, which lies I4 miles west of the promontory, was undetectable. The Land's End corner current was quite narrow.

It is clear that during 1928 we experienced a hydrographical event of considerable magnitude, the whole of the English Channel being affected. It is probable, though not completely proved, that the Biscayan water diluted by run-off from the Loire watershed turned Ushant as a quite narrow current, not more than 30 miles wide and for most of the time probably much narrower. It took ro weeks to reach Land's End at a rate of 3 miles a day by the route 
followed. When it did its tendency was to enter the Bristol Channel as a current snugging the headland and not to spread out to include the Seven Stones Light Vessel in its path. Added water alters both density and the consequent pattern of currents, particularly near Ushant. The spring of 1928 may therefore provide a pattern for the circulation of the western English Channel in spring only in years when rainfall over central and western France has been above average.

To understand the behaviour of any of these corner currents it is necessary to have very close stations in the offing and to have one as close to the headland as prudent navigation will allow.

It may not be chance that I928 and 1929 provided very poor year-classes of hake. Hickling (1935) sought a correlation with the reduced run of the wind to the eastward during the breeding season, but the presence of much fresh water and a consequent pattern of currents may have played a part.

\section{CURRENTS WEST OF USHANT IN THE SUMMER OF 1950}

The English Channel and Celtic Sea were exceptionally thoroughly surveyed in the summer of 1950 (Conseil International, 1954) by the Lowestoft research vessel 'Sir Lancelot' and by our own vessel, 'Sabella'. Valuable information was also collected by R.R.S. 'Discovery II' and R.R.S. 'William Scoresby'. The vessels worked in informal but close association. Only observations relevant to currents west and north of Ushant are here considered (Fig. 3).

The important line of surface observations between Land's End and Ushant (no. Io) also requires special comment. This is operated on fortnightly schedules out and home by two ships which often pass each other in the mouth of the Channel. In the early months of 1950 serious discrepancies between temperature observed by each ship and those observed at the Seven Stones Light Vessel and by R.V. 'Sabella' were noted. By such comparison and by scrutinizing the times of observation, we have had good reason to reject observations from one ship for the whole year and from the second ship for the months of January, February and March. Observations from the second ship have been accepted for the following dates and are included in the isopleth (Fig. 2). It is understood that the Lowestoft Laboratory have arrived at a similar conclusion.

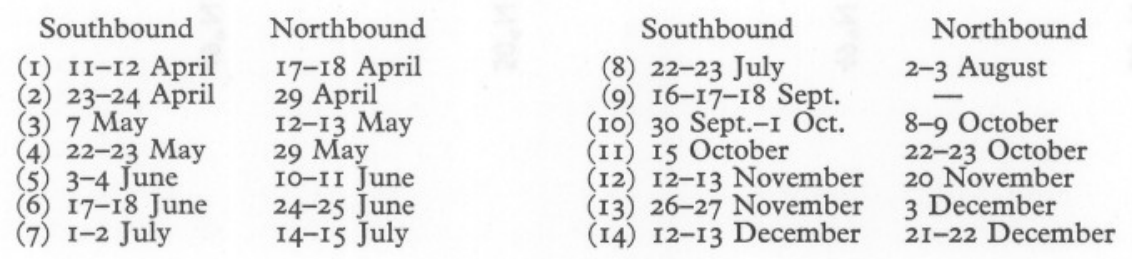


TEMPERATURE

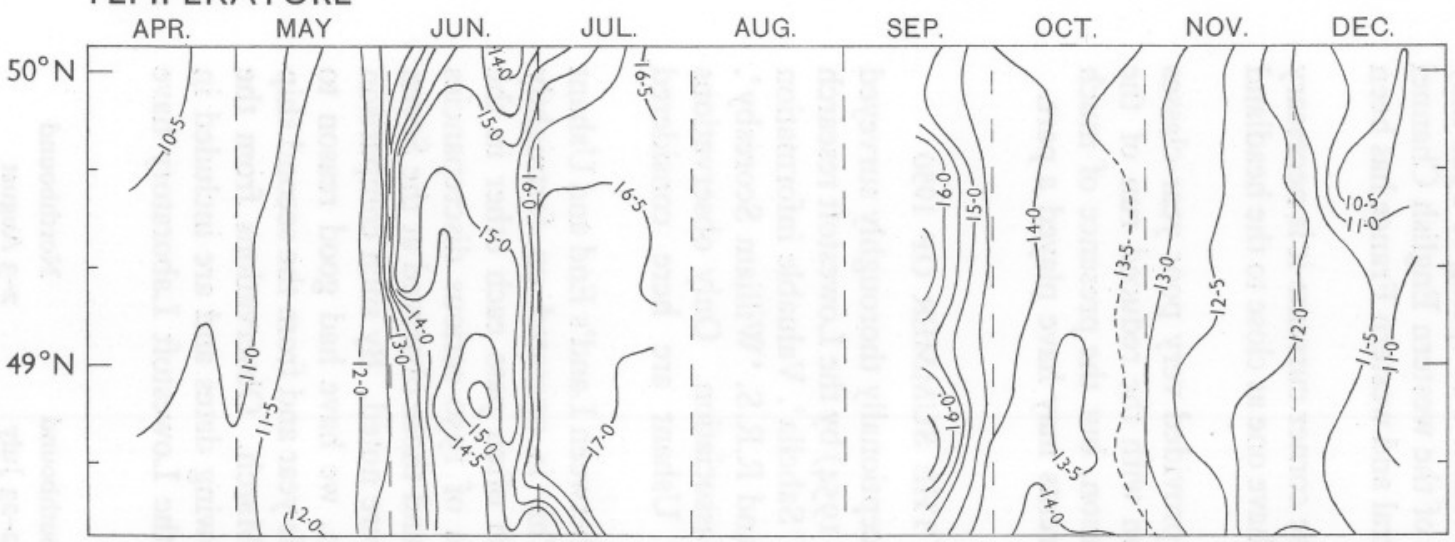

\section{SALINITY}

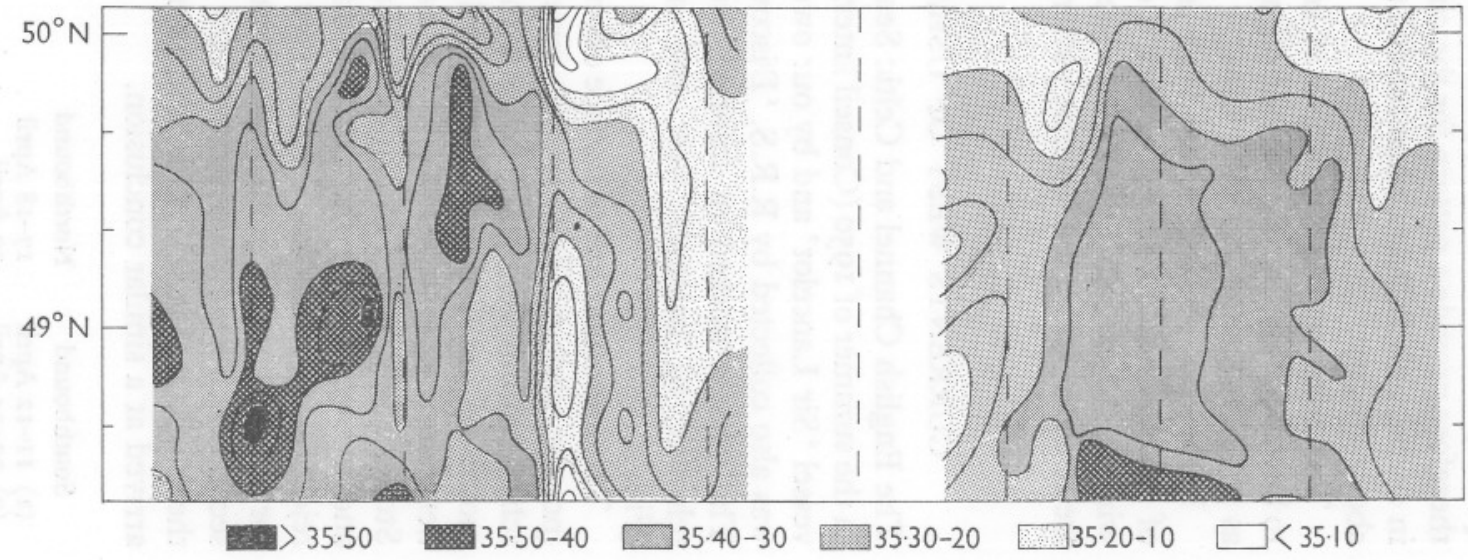

Fig. 2. Selected surface observations of temperature $\left({ }^{\circ} \mathrm{C}\right)$ and salinity $(\%)$ along line no. ro between Land's End and Ushant. Time (April-December I950) plotted against latitude. 
'Sir Lancelot's' observations in August 1950

In August R.V. 'Sir Lancelot' worked a line of stations west of Ushant at even closer intervals than those of R.V. 'Sabella' in June and additionally made highly critical observations north of north-western Brittany (Fig. 3).
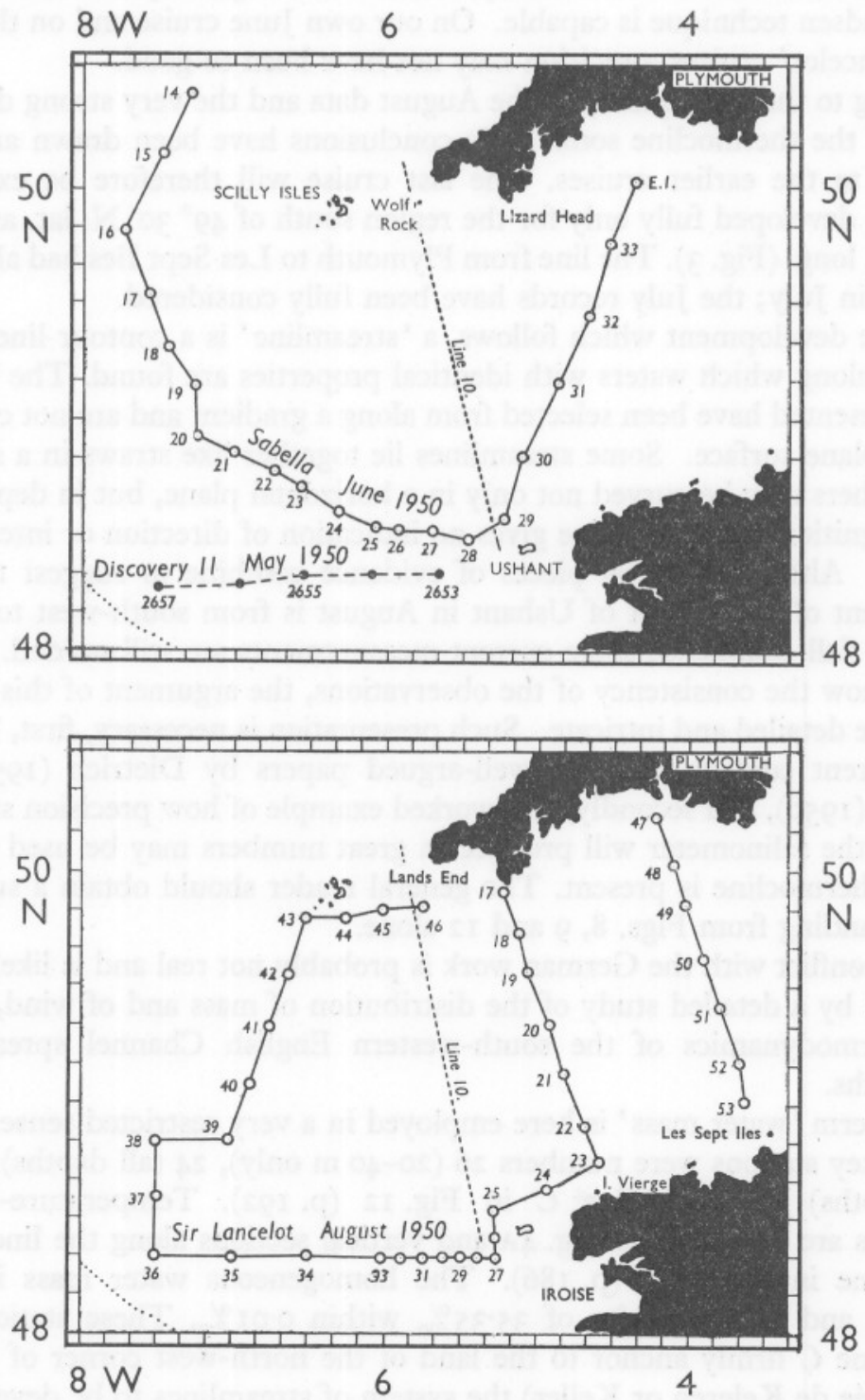

Fig. 3. Positions of observations in 1950 discussed in this paper. Upper diagram, 'Discovery' stations $2653-57$ on II May and 'Sabella' stations I6-33 on I2-I4 June. Lower diagram, 'Sir Lancelot' stations $17-53$ on 6-13 August. Surface observations on line ro are indicated. 
The homogeneity of the August observations when plotted on temperature and salinity (T-S) diagrams was very good. Such few errors in salinity as there may have been were relatively gross (of the order $\pm 0 \cdot 1 \%$ salinity), suggesting leaky stoppers. Otherwise it would seem that the analyses, made in the Government Chemists' Laboratory, attained the highest precision of which the Knudsen technique is capable. On our own June cruise and on the other 'Sir Lancelot' cruises, precision may not have been so good.

Owing to the high quality of the August data and the very strong development of the thermocline some basic conclusions have been drawn and then applied to the earlier cruises. The last cruise will therefore be examined first but developed fully only for the region south of $49^{\circ} 30^{\prime} \mathrm{N}$. lat. and west of $4^{\circ} \mathrm{W}$. long. (Fig. 3). The line from Plymouth to Les Sept Iles had also been worked in July; the July records have been fully considered.

In the development which follows, a 'streamline' is a contour line within the sea along which waters with identical properties are found. The streamlines presented have been selected from along a gradient and are not confined to any plane surface. Some streamlines lie together like straws in a sheaf of corn, others may be curved not only in a horizontal plane, but in depth also.

Recognition of a streamline gives no indication of direction or intensity of current. Although several pieces of evidence combine to suggest that the movement of water west of Ushant in August is from south-west to northeast, for full confidence some current measurements are still needed.

To show the consistency of the observations, the argument of this section has to be detailed and intricate. Such presentation is necessary, first, because of apparent conflict with the well-argued papers by Dietrich (I950) and Hansen (I950), and secondly, as a worked example of how precision salinities such as the salinometer will produce in great numbers may be used when a strong thermocline is present. The general reader should obtain a sufficient understanding from Figs. 8, 9 and $\mathrm{I} 2$ alone.

The conflict with the German work is probably not real and is likely to be resolved by a detailed study of the distribution of mass and of wind, and of the thermodynamics of the south-western English Channel spread over I2 months.

The term 'water mass' is here employed in a very restricted sense.

The key stations were numbers 26 (20-40 m only), 24 (all depths) and 22 (all depths) on streamline $C$ in Fig. I2 (p. I92). Temperature-salinity diagrams are displayed as Fig. 4A and vertical sections along the line of the streamline in Fig. 7, $C$ (p. I86). The homogeneous water mass is there stippled and has a salinity of $35.35 \%$ within $0.01 \%$. These stations and streamline $C$ firmly anchor to the land of the north-west corner of Ushant (Chaussée de Keleren or Keller) the system of streamlines to be developed.

The water at station 26 , at $75 \mathrm{~m}$ and deeper (salinity $35 \cdot 37-35 \cdot 39 \%$, temperature $12 \cdot I^{\circ}$ ) was not moving east into the English Channel, neither 
was the water at 0 and $10 \mathrm{~m}$ depth where the salinity of $35.32 \%$ was not elsewhere recognized. Our interest rests on the water between 20 and $50 \mathrm{~m}$ with a salinity of $35.35 \%$ precisely and a range of temperature between I2.05 and $14.4^{\circ} \mathrm{C}$. This water passed between station 25 and the Island of Ushant. Indeed there is no doubt that with the help of the strong tide it
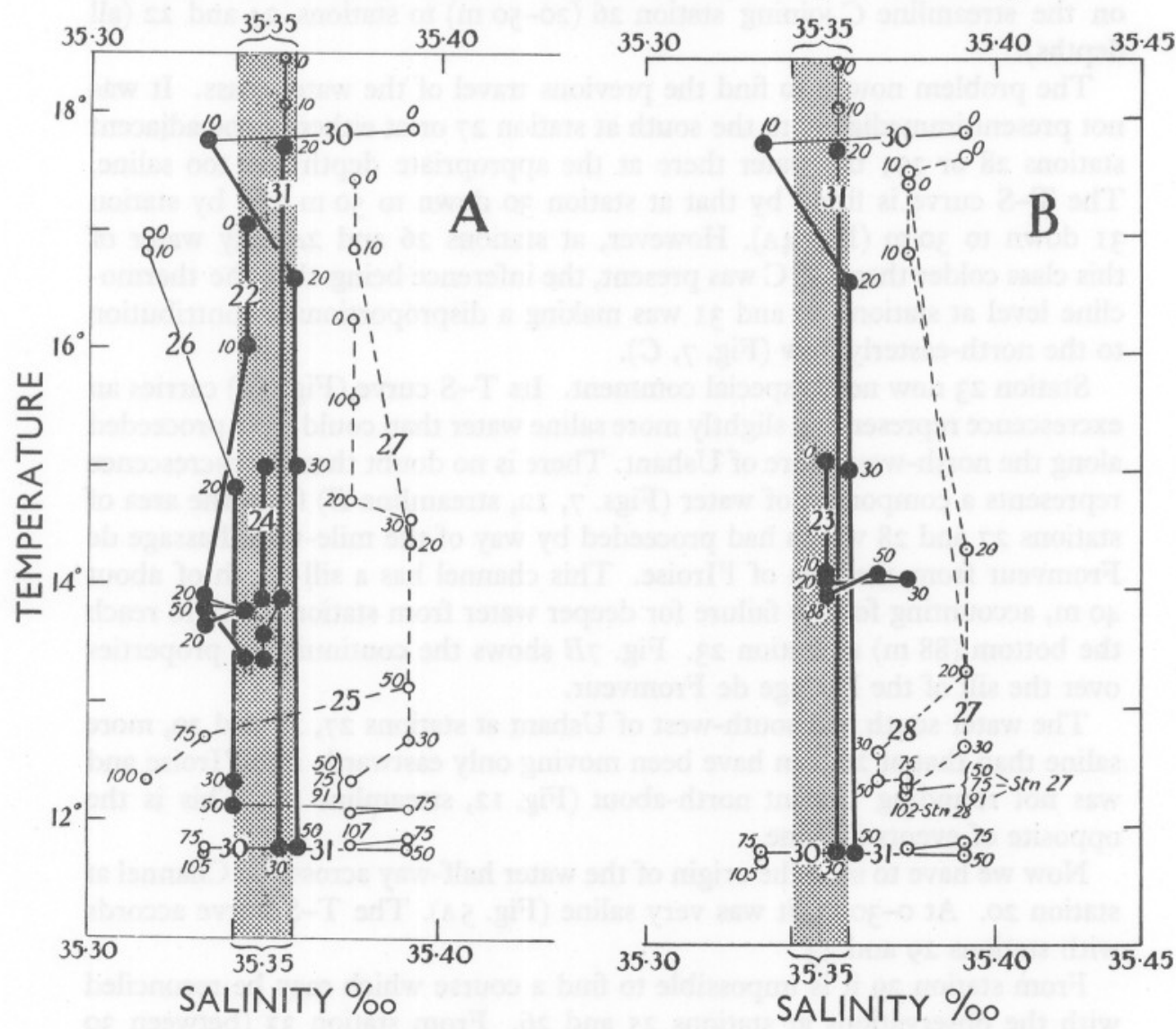

Fig. 4. Temperature-salinity diagrams from which the streamlines in Fig. I2 have been constructed: A, streamline $C$; $\mathrm{B}$, streamline $B$. Cf. Figs. $7 \mathrm{~B}, \mathrm{C}$ and 9 . To display the many points with salinity $35.35 \%$, the vertical line has been expanded into the shaded band.

suffered considerable vertical mixing as it passed over the bottom in 38 $50 \mathrm{fm}$. (70-90 m), between the steep-to submarine cliff of the Chaussée de Keleren and the off-lying submarine fosse to become the water mass observed at station 24 . Here the salinity was unchanged and the range of temperature was reduced by mixing to $13.35^{-1} 3.85^{\circ} \mathrm{C}$ at $10-90 \mathrm{~m}$ depth. All the water at station 24 proceeded unchanged to station 22 where it was found between $20 \mathrm{~m}$ and the bottom at $97 \mathrm{~m}$. 
The warmer water at station 22 (0-10 m) had been subjected to solar insolation. Its properties are compatible with a flow of water from station 30 (I5-25 $\mathrm{m}$ deep) I5 miles west of Ushant.

On Fig. 4A, T-S curves (pecked) for stations 25 and 27 are included to show that the waters there were quite markedly different from that on the streamline $C$ joining station $26(20-50 \mathrm{~m}$ ) to stations 24 and 22 (all depths).

The problem now is to find the previous travel of the water mass. It was not present immediately to the south at station 27 or at either of the adjacent stations 28 or 29 ; the water there at the appropriate depth was too saline. The T-S curve is fitted by that at station 30 down to $50 \mathrm{~m}$ and by station $3 \mathrm{I}$ down to $30 \mathrm{~m}$ (Fig. 4A). However, at stations 26 and 24 only water of this class colder than $15^{\circ} \mathrm{C}$ was present, the inference being that the thermocline level at stations 30 and 31 was making a disproportionate contribution to the north-easterly flow (Fig. 7, C).

Station 23 now needs special comment. Its T-S curve (Fig. 4B) carries an excrescence representing slightly more saline water than could have proceeded along the north-west shore of Ushant. There is no doubt that the excrescence represents a component of water (Figs. 7, 12, streamline $B$ ) from the area of stations 27 and 28 which had proceeded by way of the mile-wide Passage de Fromveur from the area of l'Iroise. This channel has a sill depth of about $40 \mathrm{~m}$, accounting for the failure for deeper water from station $27 / 28$ to reach the bottom $(88 \mathrm{~m})$ at station 23 . Fig. $7 B$ shows the continuity of properties over the sill of the Passage de Fromveur.

The water south and south-west of Ushant at stations 27, 28 and 29, more saline than that at 26 , can have been moving only eastwards into l'Iroise and was not rounding Ushant north-about (Fig. I2, streamline $A$ ). This is the opposite of events in June.

Now we have to seek the origin of the water half-way across the Channel at station 20. At o-30 m, it was very saline (Fig. 5A). The T-S curve accords with stations 29 and 33 .

From station 29 it is impossible to find a course which may be reconciled with the observations at stations 25 and 26. From station 33 (between 30 and $45 \mathrm{~m}$ depth) the course (Fig. I2, streamline $E$ ) fits with the story that has still to be told.

Below $30 \mathrm{~m}$ at station 20 a different water mass was present. An origin from a position half way between stations 28 and 29 (not here illustrated) fits the T-S diagrams but is inconsistent with other stations or the pattern of geopotential anomalies. The vertical column at station 20 has therefore to be fitted by a surface sloping from a depth of about $28 \mathrm{~m}$ at station 32 (which sinks to the bottom at station 20) and $40 \mathrm{~m}$ at station 33 (which rises to $30 \mathrm{~m}$ at station 20 ). That is between stations $33 / 32$ and 20 , the T-S surface executed what an aviator would call a roll through more than a right-angle 


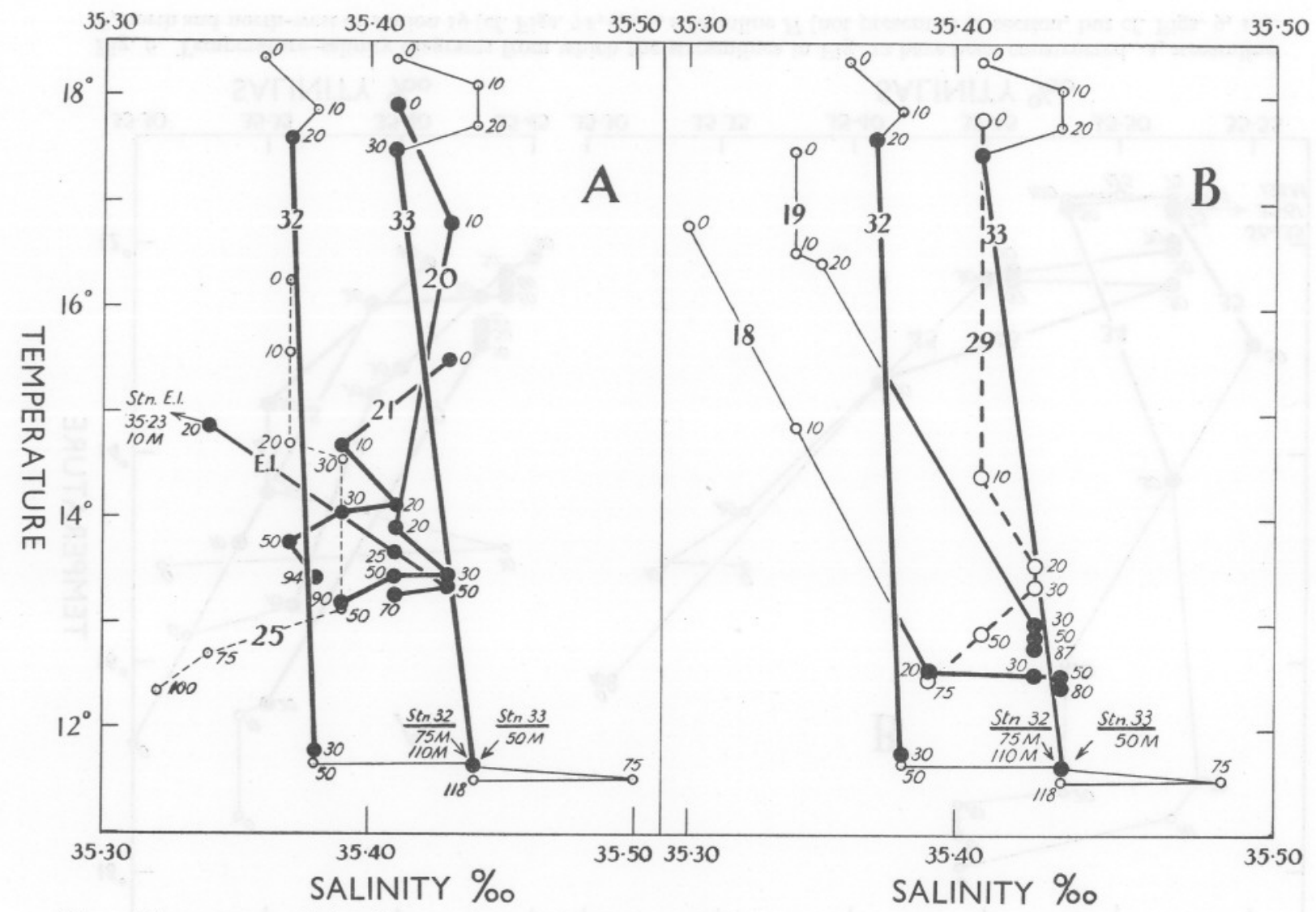

Fig. 5. Temperature-salinity diagrams from which the streamlines in Fig. I2 have been constructed: A, streamlines $D$ and $E$ (cf. Figs. 7 D, 8, 9); B, streamline $F$ as far as station 18 (cf. Figs. 7 F, 9). 

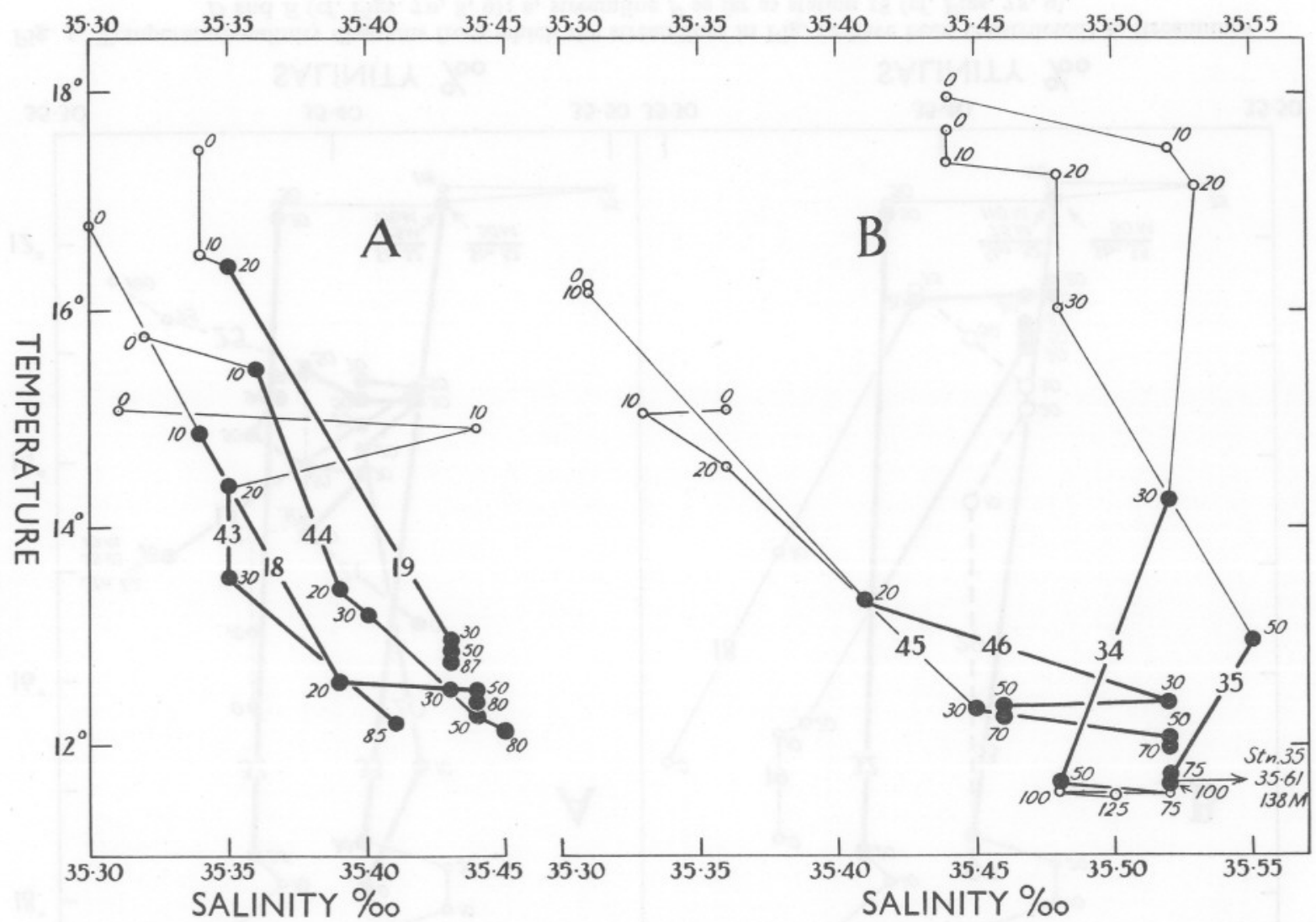

Fig. 6. Temperature-salinity diagrams from which the streamlines in Fig. 12 have been constructed. A, streamline $F$, north and north-west of station I9 (cf. Figs. 7F, 9); B, streamline $H$ (not presented in section, but cf. Figs. 9, I2). 
(Fig. 8). The direction of the roll was clockwise as the water advanced. In this deduction, temperature may legitimately be treated as a near-conservative quantity, since the water mass always remained subthermocline; Fig. 8 is necessarily somewhat schematic. It is not practicable to present this helical movement for every streamline though the tendency is present on all of them. Streamline $E$ can be followed to 'Sula's' station E I worked on 23 August (Figs. 5A, 8 and I2).

The water from station 32 (about $28 \mathrm{~m}$ depth), following streamline $E$ in Fig. I2 passed station 25 at a depth of $50 \mathrm{~m}$ (Fig. 8) on its way to the bottom $(90 \mathrm{~m})$ at station 20 , undercutting streamline $D$. Streamlines $D$ and $E$ at all points lay to the seaward of streamline $C$ but north-west of Ushant by only a few miles.

Station 2I (Figs. 5A, 7) shows a similar history to station 20, but a larger proportion of the water came from the neighbourhood of station 32 and less from that of station 33. Moreover, the subthermocline water at station 2I was half a degree warmer than that at station 20 and consequently was somewhat higher within the thermocline at station 32 .

A probable crossing-over between streamlines $D$ and $E$ represents water from station 32 which has passed station 25 at $50 \mathrm{~m}$ and then undercut somewhat shallower water on passage from midway between stations 32 and 33 at about $35 \mathrm{~m}$ north of station 25 to $2 \mathrm{I}(40-90 \mathrm{~m})$. For clarity it has been eliminated from Fig. I2. It is not easy to represent the fanwise spreading and interlacing of these waters on plane diagrams.

Now let us consider (Figs. 5B, 7) stations I 9 and I8, 24 and I4 miles S.S.E., respectively, of the Lizard. At this distance surface warming-up will have destroyed any hope of finding the history of the water above the thermocline but it would seem that temperature remained conservative below the thermocline. The very saline water $\left(35.43-35.44 \%\right.$ and temperature $\left.12.47-12.92^{\circ} \mathrm{C}\right)$ between $30 \mathrm{~m}$ depth and the bottom at $82-87 \mathrm{~m}$ accords closely with the water in the lower part of the thermocline at station 33 (Figs. 5 B and I2, streamline $F$, and the streamline $F$ section in Fig. 7). Thus the water from station 33 was spreading fanwise, the upper thermocline water taking a more easterly direction than the deeper.

It would seem that 'Sir Lancelot' section between the Lizard and l'Ile Vierge, as between stations 20 and I8, lay almost along the line of movement of the current which had passed station $33\left(48^{\circ} 20^{\prime} \mathrm{N}\right.$., $6^{\circ} \circ \mathrm{oO}^{\prime} \mathrm{W}$.) at thermocline level.

This same water mass may be followed farther to station 44 south of Scilly (Fig. 12, streamline $F$, Fig. 6A, Fig. 7). Streamline $F$ would seem to have passed north of stations 45 and 46 , nearby the Wolf Rock. Still farther north another streamline $(G)$ can be traced (Figs. I2, 6A) from station I8 (20 m, at the bottom of the thermocline there) to 43 ( $30 \mathrm{~m}$ to bottom in $85 \mathrm{~m}$ ), i.e. along the south coast of Cornwall water which had crossed the Channel at the 

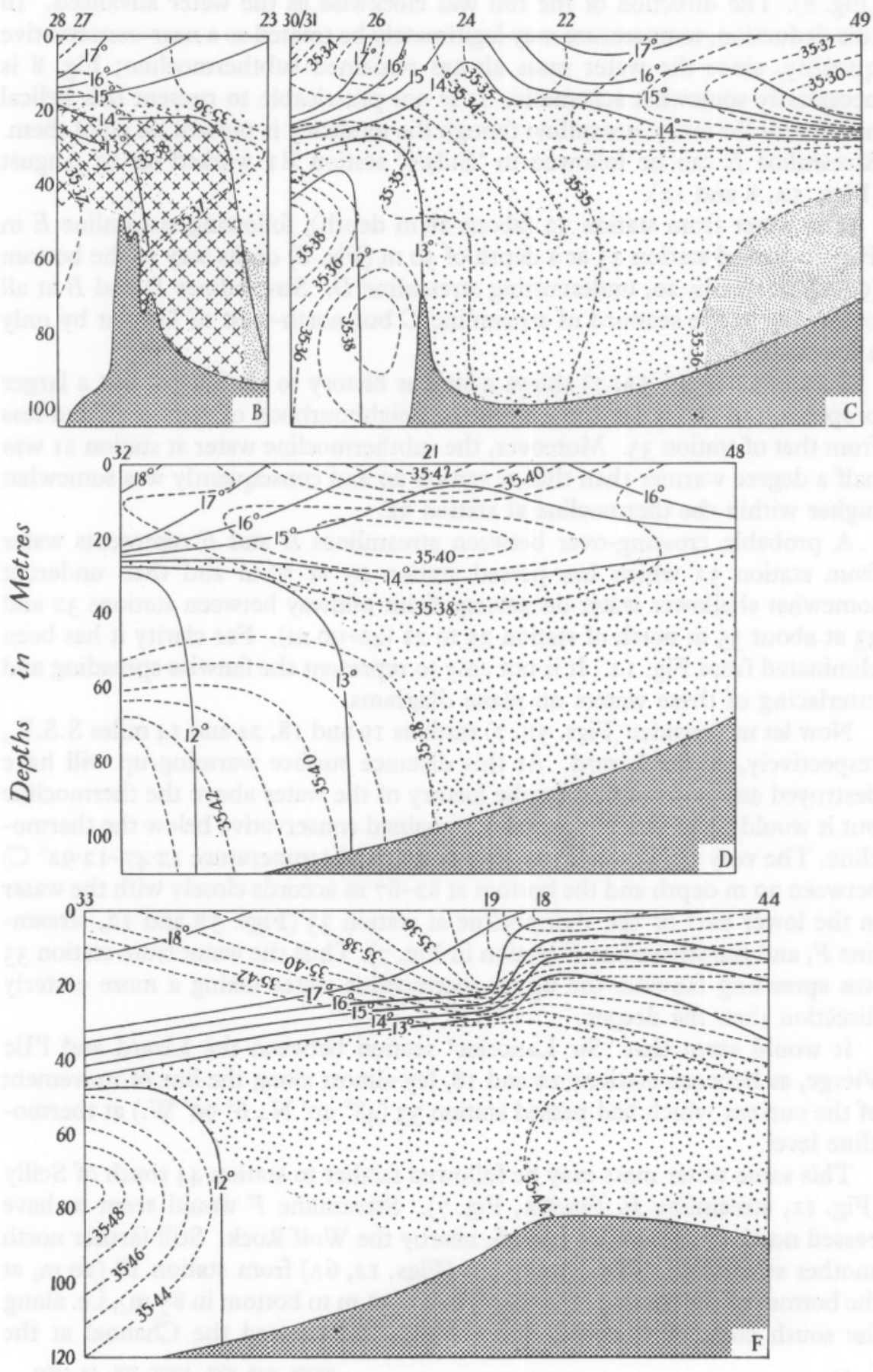

Fig. 7. For legend see opposite page. 
bottom of the thermocline sank below a coastal belt of surface water to cover the submarine slope between 50 and $80 \mathrm{~m}$ depth.

The higher salinities at station $46(30 \mathrm{~m})$ and station $45\left(49^{\circ} 50^{\prime} \mathrm{N}\right.$., south of the Land's End-Scilly Channel; at 50 and $70 \mathrm{~m}$ ) are consistent with an origin in the lower part of the thermocline between stations 34 and 35 $\left(48^{\circ} 20^{\prime}\right.$ N., $6^{\circ} 45^{\prime}$ W., Parsons Bank area) (Fig. I2, streamline H, Fig. 6B).

The course of this concordant family of streamlines at the lower level is summarized in Fig. I2. They show that in the weeks preceding 6 August 1950, there had been a cyclonic circulation in the subthermocline water in the mouth of the English Channel and that most of this water had been introduced across the parallel $48^{\circ} 20^{\prime} \mathrm{N}$., at thermocline level in a current there flowing east-north-east and grazing the north-west corner of Ushant. The destinations of the various parts of the thermocline structure along the parallel $48^{\circ} 20^{\prime} \mathrm{N}$., are displayed in Fig. 9.

A spiral, the mirror image of the Ekman spiral, was evident west and north of Ushant, the water in the upper part of the thermocline along the parallel $48^{\circ} 20^{\prime} \mathrm{N}$. proceeding to the right of that in the lower part of the thermocline there. Very little of the water truly below the thermocline moved into the English Channel. Such movement as it had was probably north-west.

So far we have examined the manner by which water which crosses the line west of Ushant within the thermocline fans out and deepens to become the subthermocline water on the line between the Lizard and l'Ile Vierge.

\section{Legend to Fig. 7}

Fig. 7. Sections along streamlines sublettered to correspond with Fig. I2.

Streamline $B$ (area coarsely stippled) passes through the Passage de Fromveur between Ushant and the mainland of France (cf. T-S diagram, Fig. 4B). The water at $88 \mathrm{~m}$ at station 23 was identical with that at 8-9 $\mathrm{m}$ at station 24 , i.e. at the top of the water in streamline $C$ (next panel) which had sunk towards the east. Much of the cross-hatched water blanketing the slope of l'Ile Vierge inside of station 23 had unknown properties; to fit with the rest of this account it needed to have the properties of stations 27 and 28 between 20 and $50 \mathrm{~m}$ ( $\mathrm{T}-\mathrm{S}$ diagram, Fig. 4B, pecked lines).

Streamline $C$ was anchored snugly to the north-west corner of Ushant (Chaussée de Keleren) (cf. T-S diagram, Fig. 4A). All but one of the points in the coarsely stippled area had a salinity precisely $35.35 \%$, so that only a generalized iso-line may be drawn for that salinity. The odd point was $35.34 \%$. The bottom water at station 49 was part of streamline $D$.

Streamline $D$ (cf. T-S diagram, Fig. $5 \mathrm{~A}$, in part), lying to seaward of streamline $C$, is stippled: The elongated core of water at station $2 \mathrm{I}$ at between $\mathrm{I} 2$ and $28 \mathrm{~m}$ depth and having a salinity in excess of $35.39 \%$ had crossed the meridian $48^{\circ} 20^{\prime} \mathrm{N}$. at $5^{\circ} 56^{\prime} \mathrm{W}$. between stations 32 and 33 at a depth between 26 and $33 \mathrm{~m}$. On Fig. 9, if inserted, it would show as a callosity on the left of streamline $D$. At station $2 \mathrm{I}$ it passed above section $D$ and proceeded to station 5 I as streamline $Q$ (Fig. IOQ).

Streamline $E$ cannot be presented as a vertical section. Its helical character is shown schematically in Fig. 8. It undercuts streamline $D$ at station 25 at a depth of $50 \mathrm{~m}$ (cf. T-S diagram, Fig. 5A).

Streamline $F$ (stippled) was established from a point 45 miles west of Brittany, across the mouth of the Channel, then south of Land's End and Scilly (cf. T-S diagrams, Figs. 5B, 6A). 
The same process was at work in the thermocline on the Lizard-l'Ile Vierge line. Fig. Io shows sections $P$ and $Q$ joining stations 22 and 52 and stations $2 \mathrm{I}$ and $5 \mathrm{I}$, where thermocline water is moving to the right of the water below the thermocline and sinking as it moves up-Channel. This is what might be expected of an anticlockwise gyral in the wide-mouth of a narrowing and shallowing channel in high summer.

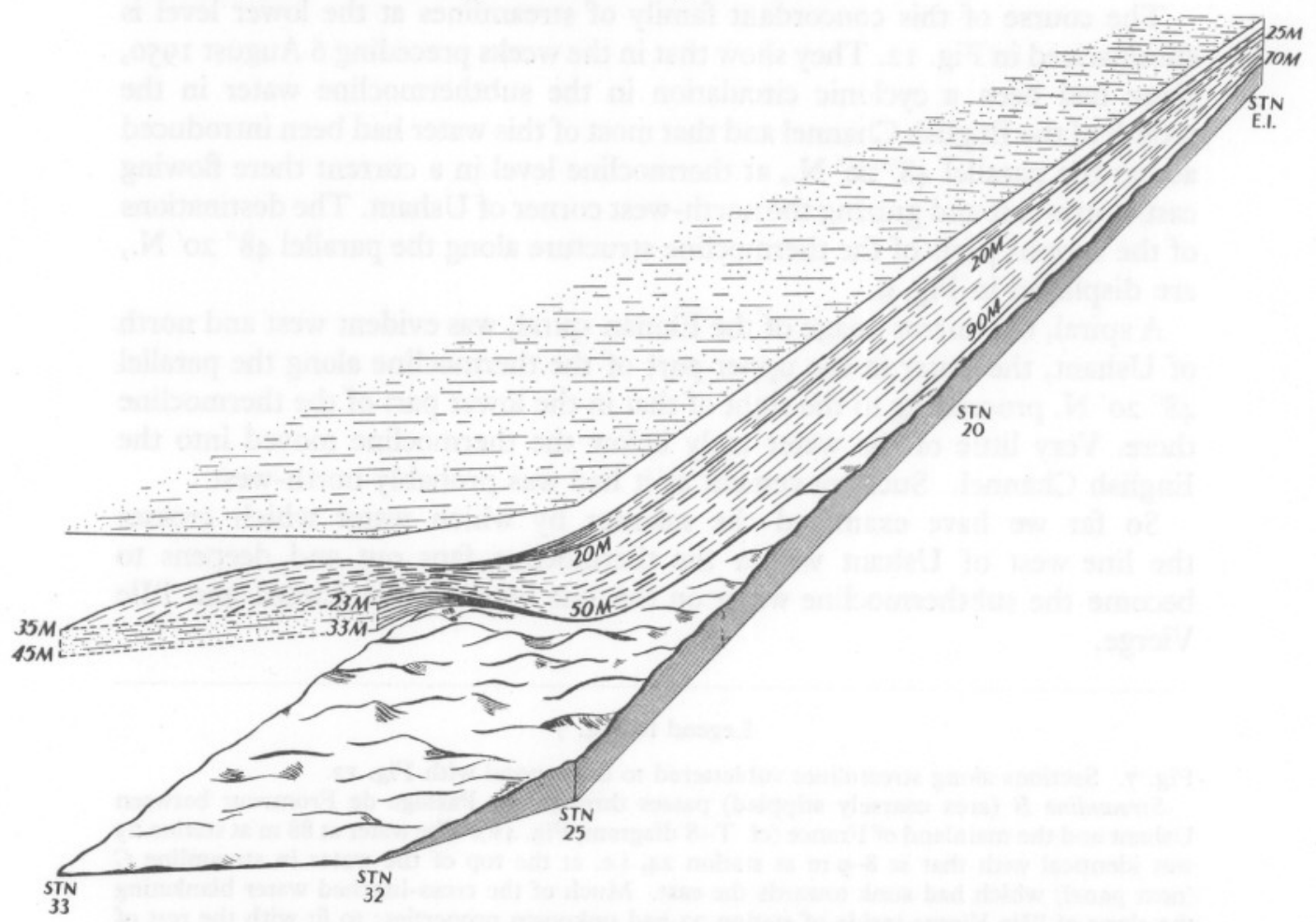

Fig. 8. A block diagram to show how water lying horizontally in the thermocline west of Ushant twists in a vertical plane through a right angle as it passes north-west of Ushant to occupy the subthermocline vertical column in mid-Channel (station 20) and at EI. The lower contour passes through the position of station 25 at $50 \mathrm{~m}$ depth. The upper contour, however, passes not through station 25 but through a position some miles to the north-west. Some displacement of the isotherms and isohalines drawn in Fig. 7D is necessary but is compatible with the observations.

The course of these streamlines $P$ and $Q$ is also shown in Fig. I2. Streamlines $P, Q$ and $G$ lie above streamlines $C, D$ and $F$ where they cross.

The boundary between the easterly current (streamlines $P$ and $Q$ ) and the deeper northerly or north-easterly current (streamlines $C, D$ and $E$ ) was sharp. There is no evidence for water at the boundary depth at stations 20 , $2 \mathrm{I}$ and 22 moving in an intermediate direction.

Consequently the thermocline 30 miles N.N.E. of Ushant was different 


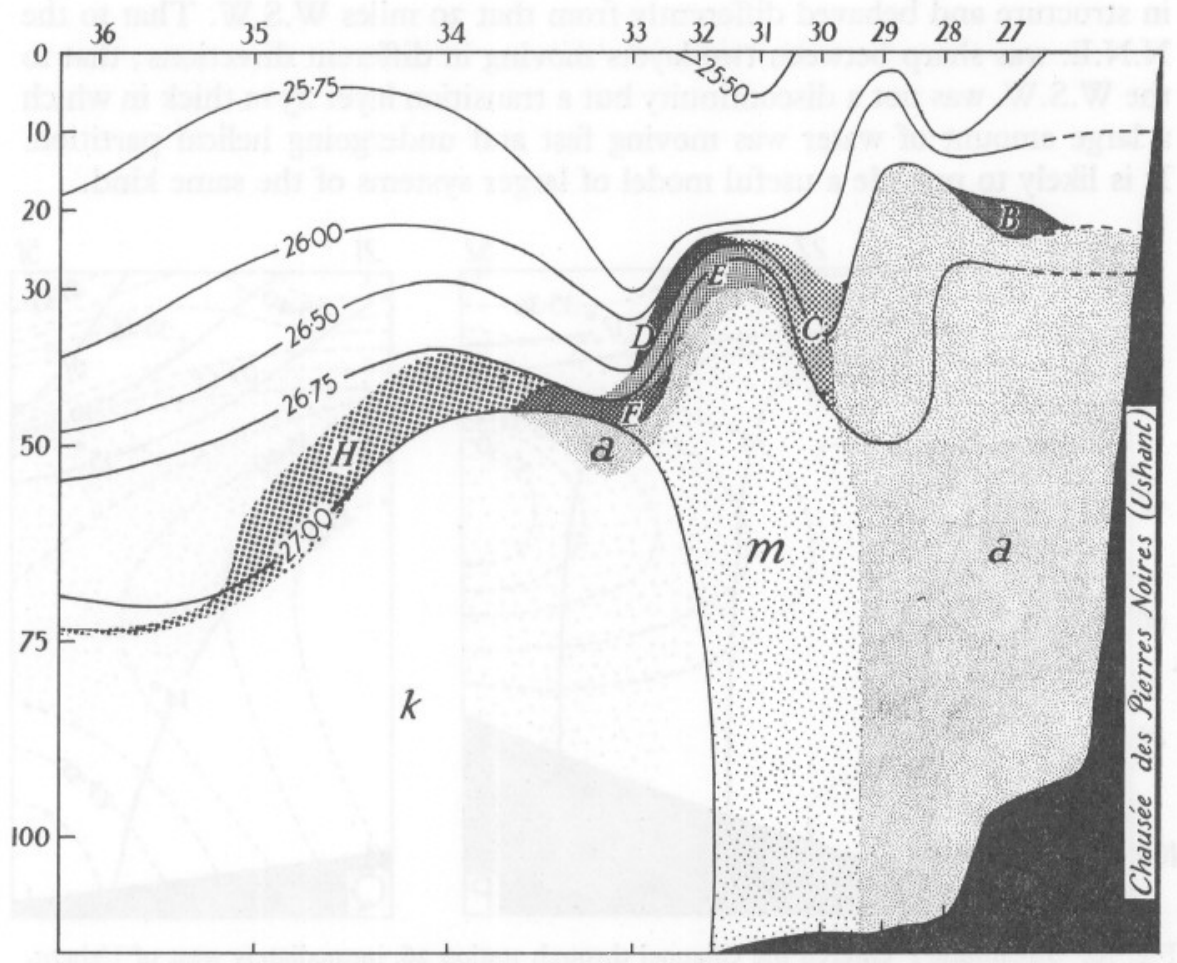

Fig. 9. Density $\left(\sigma_{t}\right)$ section west of Ushant along lat. $48^{\circ} 20^{\prime} \mathrm{N}$. on 7 August I950 with destinations of the water in and below the thermocline. Waters which were to enter the English Channel east of a line drawn from Ushant to Scilly are denoted by capital letters, whereas lower case letters indicate waters which were not to enter the Channel.

Water masses $C, D, E$ and $F$, subcomponents of one current system, were to flow along the corresponding streamlines (Fig. 12, also Figs. 4A, 5 A, B, 6A) north-west of Ushant into the English Channel to occupy the whole water column between about $25 \mathrm{~m}$ and the bottom. Water mass $H$ (Figs. I2, 6B) was to follow a similar course (streamline $H$ ) across the mouth of the Channel to a region south of the Wolf Rock.

The deep westerly water mass $k$ was probably moving relatively slowly. Such movement as it had was towards the north. It never entered the English Channel.

Water mass $m$ represents a vertical planar section of a spiral eddy. Near station 32 at about $45 \mathrm{~m}$ depth, the lowest water in the thermocline had a northerly spiral component. This flowed north-about station $3 \mathrm{I}$ and below water masses $F$ to $C$ to return as a slow current with a southerly component and occupying at station 30 all the water column below a depth of $50 \mathrm{~m}$.

Similarly water mass $a$ first lay in a vertical plane at $30-55 \mathrm{~m}$ between the water masses $F-D$ which were to enter the English Channel and the water at the deep centre of the eddy $(m)$. It also rotated, undercutting water mass $C$ to become the deep water (below $20 \mathrm{~m}$ ) in l'Iroise at stations 29,28 and 27 . The horizontal planar projection of the flow of water mass $a$ is indicated on Fig. 12 as streamline $A$.

Apart from tidal movement water mass $a$ in l'Iroise was probably almost stagnant in August. The small kernel of water marked $B$, to correspond with streamline $B$ in Fig. 12, was really part of water mass $a$ but in a position to be carried on the flood tide through the Passage de Fromveur to station 23 at $30-50 \mathrm{~m}$ depth (Fig. $4 \mathrm{~B}$ ).

Streamline $P$ (Fig. IO) entered as a thin band of water immediately overlying water mass $C$ in this figure; similarly the origin of streamline $Q$ overlay streamline $D$. On this figure they are not easy to depict. 
in structure and behaved differently from that 30 miles W.S.W. That to the N.N.E. was sharp between two layers moving in different directions; that to the W.S.W. was not a discontinuity but a transition layer $25 \mathrm{~m}$ thick in which a large amount of water was moving fast and undergoing helical partition. It is likely to provide a useful model of larger systems of the same kind.
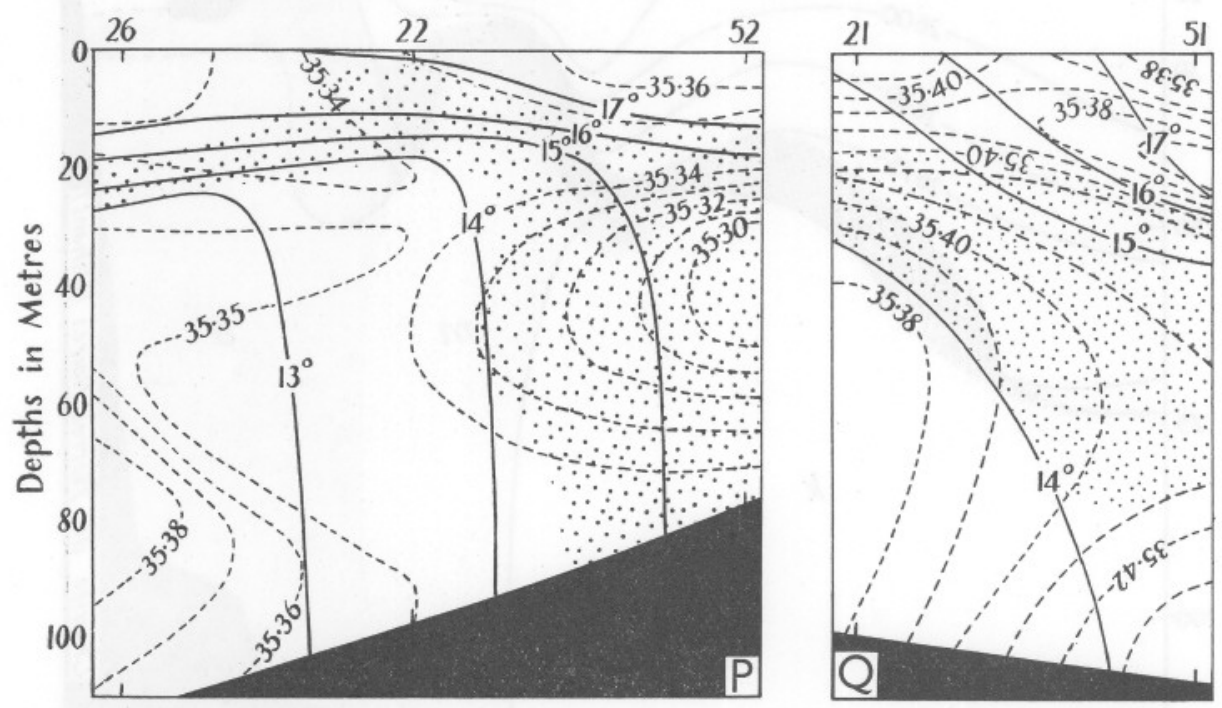

Fig. Io. Streamline $P$ entered the Channel through station 26 , immediately west of Ushant, between 19 and $27 \mathrm{~m}$, then between station 25 and the island, to seaward of station 24 and then above the thermocline at station 22 where at depths between 3 and $19 \mathrm{~m}$ it crossed streamline $C$. It then sank to occupy station 52, 45 miles E.N.E., between $12 \mathrm{~m}$ and the bottom. Streamline $P$ can be easily matched by interpolated values of temperature and salinity between stations 30 and 31 immediately above water mass $C$ in Fig. 9.

Streamline $Q$ also can be matched by interpolated values of temperature and salinity between stations 32 and 33 immediately above water mass $D$ in Fig. 9. The elongated core of water with salinity $35 \cdot 39-35 \cdot 40 \%$ at $15-32 \mathrm{~m}$ depth around station $2 \mathrm{I}$ in Fig. $7 \mathrm{C}$ represents this water mass crossing over streamline $C$ at an angle of intersection of $+40^{\circ}$. It then passed upChannel as shown here to occupy station 51 between 27 and $75 \mathrm{~m}$ depth.

The bottom water at station 51 gave an unsupported record of $14.29^{\circ} \mathrm{C}$ and $35.44 \%$. This is compatible with the water mass $a$ which having flowed past station 33 at $50 \mathrm{~m}$ depth, ran north-about stations $32,3 \mathrm{I}$ and 30 to proceed south-east into l'Iroise at station 29 (Fig. 9). However, no streamline can be constructed between any part of water mass $a$ and station $5 \mathrm{I}$ without intersecting some other streamline. The result at the bottom at station $5 \mathrm{I}$ cannot be made to fit without unwarrantable complexity. It is more reasonable to ascribe it to an error of observation.

Two ways of presenting temperature and salinity at a depth of $50 \mathrm{~m}$ are shown in Fig. II. The upper diagram shows a conventional chart where only the records from a depth of $50 \mathrm{~m}$ are considered and isotherms and isohalines 
in that plane are drawn by linear interpolation. It is grossly misleading. The lower diagram is drawn to conform with T-S diagrams, such as Figs. 4-6 and streamline drawings such as Figs. 7-9 and takes account of the changes in level of the water as it flows.
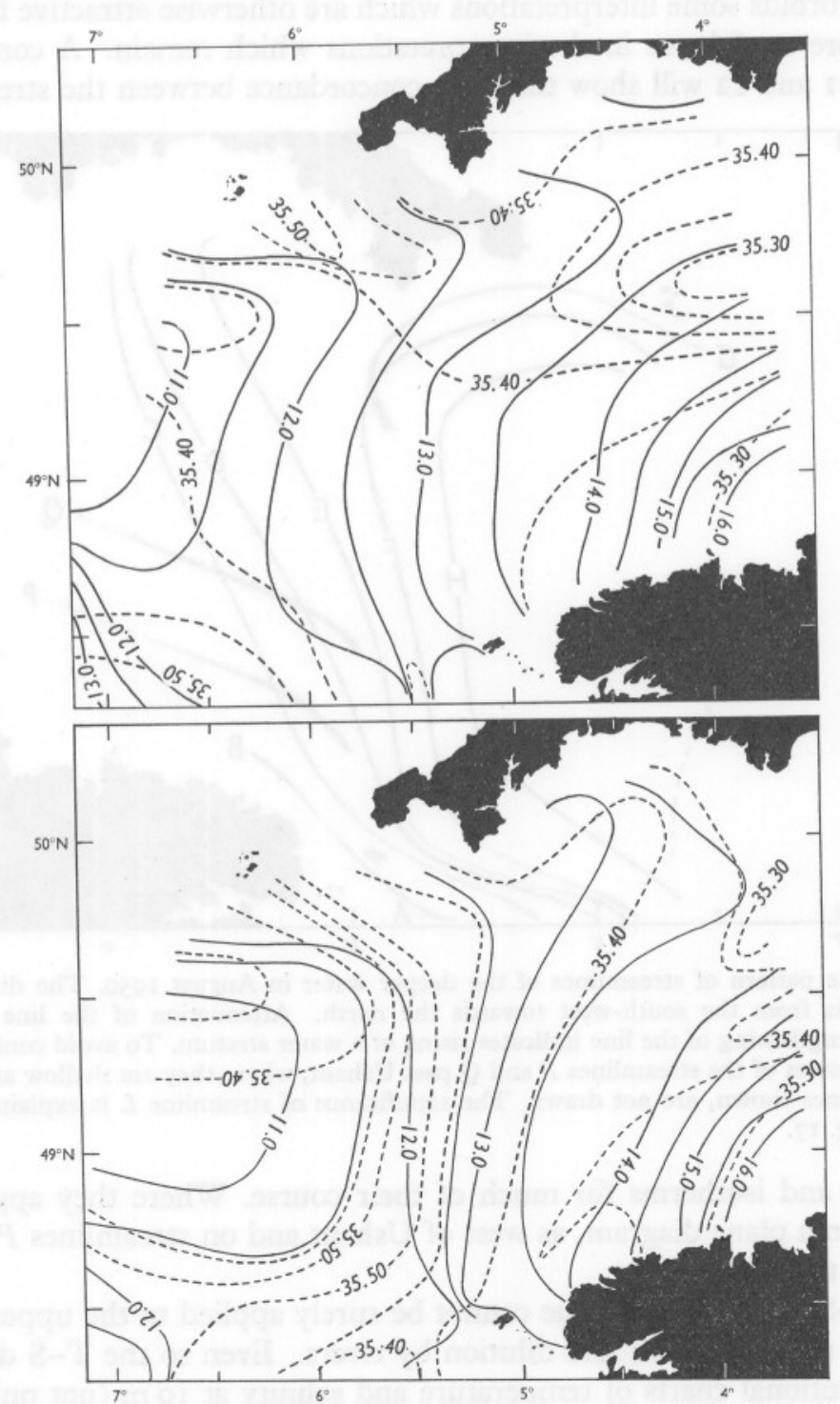

Fig. II. Two ways of constructing isotherms and isohalines at $50 \mathrm{~m}$ depth from 'Sir Lancelot's' observation between 6 and I3 August 1950. The upper panel is drawn following standard conventions; the lower one is drawn to conform with the three-dimensional pattern of streamlines (see text). The position of the stations is shown in Fig. 3 (lower). 
In shallow-water oceanography in summer, it would seem not merely interesting but essential to construct $\mathrm{T}-\mathrm{S}$ diagrams for that part of the water column which is neither in immediate contact with the atmosphere nor subject to much absorption of radiant heat. It will be found that this approach not only forbids some interpretations which are otherwise attractive but gives much more confidence in the interpretations which remain. A comparison of Figs. II and 12 will show the close concordance between the streamlines,

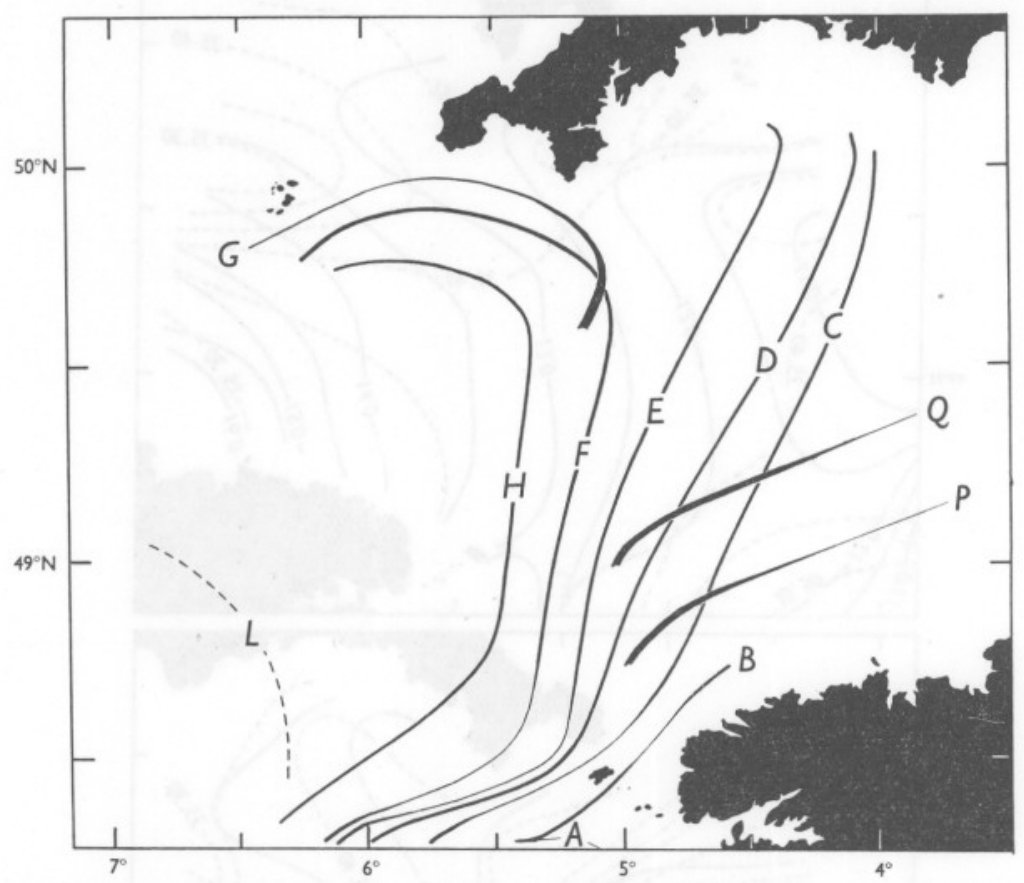

Fig. 12. The pattern of streamlines of the deeper water in August 1950. The direction of movement is from the south-west towards the north. Attenuation of the line indicates sinking, strengthening of the line indicates rising of a water stratum. To avoid confusion the southern courses of the streamlines $P$ and $Q$ past Ushant, where they are shallow and overlie the streamlines shown, are not drawn. The significance of streamline $L$ is explained in the text and Fig. I7.

isohalines and isotherms for much of their course. Where they appear not to agree on a plane diagram, as west of Ushant and on streamlines $P$ and $Q$, sinking is the cause.

The T-S diagram technique cannot be surely applied to the upper waters subject to solar radiation and dilution by rivers. Even so the T-S diagrams and conventional charts of temperature and salinity at $10 \mathrm{~m}$ (not published) give no indication that there was any appreciable surface flow across the latitude $48^{\circ} 20^{\prime} \mathrm{N}$. towards the English Channel. Most probably, as in May (to be discussed), it was towards the south-east. 
It is remarkable that even in the upper layers some measure of conservation of properties is to be recognized. On the southern end of the line from Plymouth to Les Sept Iles at stations 50, 51 and 52 there is a surface stratum of water $20 \mathrm{~m}$ thick with temperatures exceeding $17^{\circ} \mathrm{C}$ and with salinities between $34.34 \%$ and $34.39 \%$. Very similar water was present on the Lizardl'Ile Vierge line but only at the surface at stations 19 and 20 and nowhere else at any depth. The continuity of properties suggests a continuity of movement, i.e. that there was a thin surface current through stations 19 and 20 including water warmer than $17^{\circ} \mathrm{C}$, and only a few metres thick, which fanned out to the east and south-east to become a warm surface stratum four times as thick. Moreover, the water having a temperature between 16 and $17^{\circ} \mathrm{C}$ at 5 to 15 or $20 \mathrm{~m}$ depth at stations $\mathrm{I} 9$ and 20 , can also be followed but taking a somewhat more northerly direction.

This interpretation of surface water movements at high summer may be accepted only because it is compatible with the behaviour of the deeper streamlines.

The important conclusion is that there seems to have been a large recruitment of water into the mouth of the English Channel across the parallel $48^{\circ} 20^{\prime} \mathrm{N}$. between $5^{\circ} 35^{\prime} \mathrm{W}$. and $7^{\circ} \circ 0^{\prime} \mathrm{N}$. and this recruitment was from a layer at thermocline level about $20 \mathrm{~m}$ thick and forming part of a spiral the mirror image of that described by Ekman (I905) or, for tidal currents, by Hansen (1950).

Evidently, therefore, the spiral structure of the current is not controlled by wind but by the distribution of mass that comes into being when the summer sun shines on the Celtic Sea, on the water over the neighbouring continental slope and on the strongly tidal and shallow English, Bristol and Irish Channels.

Moreover, the recruitment of water to move into the English Channel, properly so-called, was confined between $5^{\circ} 35^{\prime}$ and $6^{\circ} 00^{\prime} \mathrm{W}$. long.

The whole argument requires and supports the hypothesis that when the change in density across the thermocline exceeds, say, one sigma- $t$ unit, the temperature in the underlying water and in much of the thermocline itself may be treated as a conservative property.

The derivation from continuity of properties should be and is supported by the distribution of mass along the section $48^{\circ} 20^{\prime} \mathrm{N}$. (Fig. I3). It is evident that the region between 'Sir Lancelot' stations 34 and 28 is one of strong currents or eddies, but, since there can be nothing approaching a surface of no motion and every surface slopes, it would be hazardous to deduce more than this from the geopotential topographies. They have, however, been most helpful in deciding that certain events were not possible.

This account of events associated with the month of August 1950 has had, for clarity, to be presented as though we then had an equilibrium state. Nothing is more certain than that we did not. Two points are at issue.

(a) We have traced streamlines between two or more points but the water 
in question had passed the first position some considerable time before it was observed at the later one. During this period of time the streamline may have writhed like a serpent in all three dimensions of space. Horizontal displacements may have amounted, and probably did, to many miles. Consequently

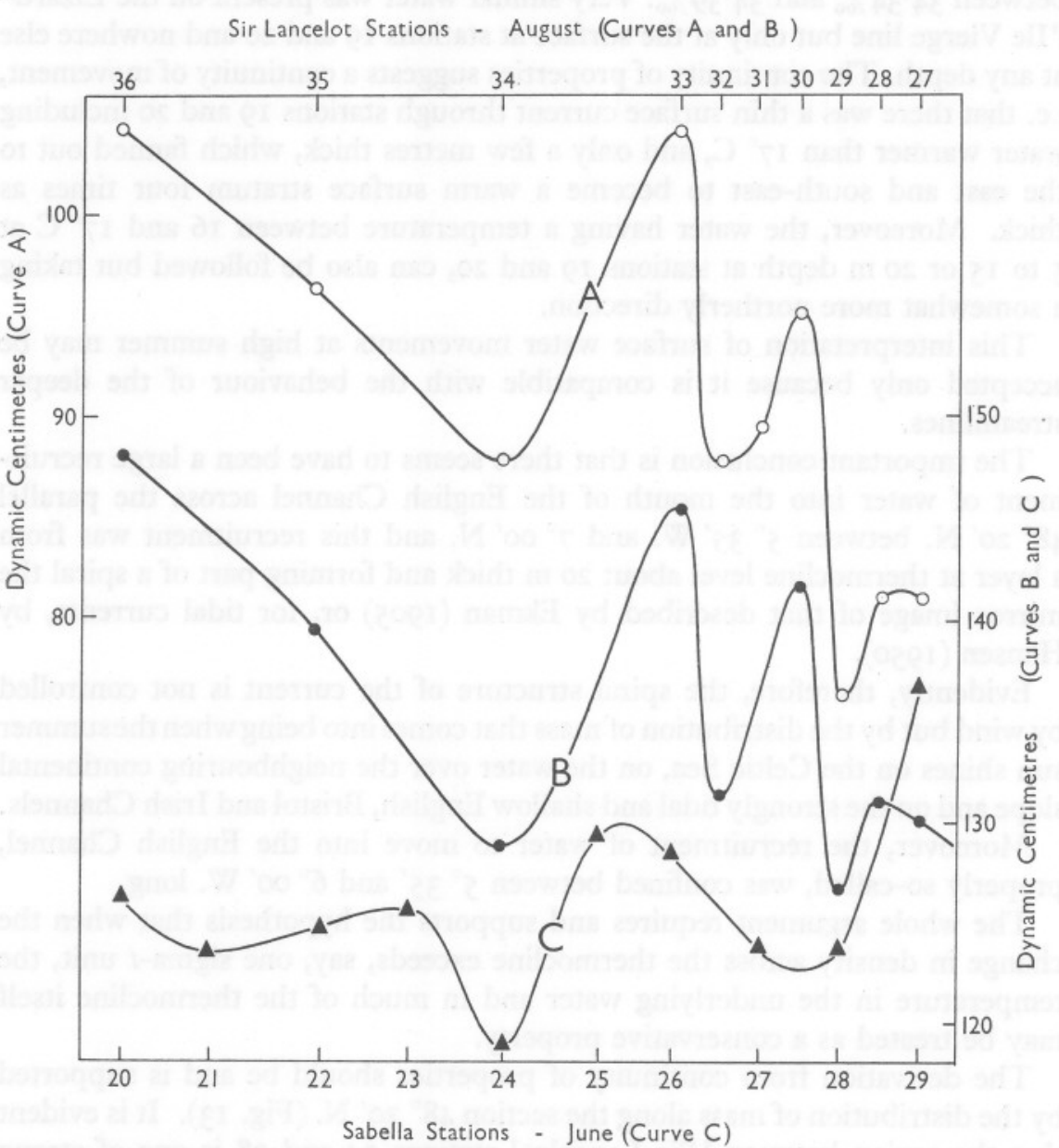

Fig. 13. Geopotential topographies: A, 'Sir Lancelot', 7 August 1950 , along lat. $48^{\circ} 20^{\prime} \mathrm{N}$., 0-50 db; B, the same, O-100 db; c, 'Sabella', 13 June 1950, west of Ushant, O-100 db. For station positions see Fig. 3.

at the time any water mass had crossed the parallel $48^{\circ} 20^{\prime} \mathrm{N}$., its position may have been many miles from the position indicated in August. Streamlines have to be related to the sea water and not to the sea bed over which the water is passing.

(b) Smooth uniform flow at any depth in the sea seems to be rare. The 
bolus concept (Cooper, 1957) first developed for water cascading over a continental slope seems to be equally applicable to current systems over a continental shelf. Movement seems to proceed in surges, carrying boluses of water. Consequently the streamlines described must not be considered as bounding simple geometrical figures. When a surge of water passes, the streamlines bounding a water mass will expand to encompass a large body of water with similar properties. Between surges, the streamlines will close up, even to be nipped out altogether. Then very little of the characteristic water would be present.

In the past we have considered that the warming up during the summer of the deeper water at our station $\mathrm{E}_{\mathrm{I}}$ has been due to turbulent transport of heat vertically across the thermocline. This investigation suggests that this is an unnecessary hypothesis and that the rise in temperature after the thermocline is strongly developed is better explained by transport and sinking of water from the thermocline at and south of lat. $48^{\circ} 20^{\prime} \mathrm{N}$. The origin of this thermocline, in its turn, now needs to be sought. Since this change of view has considerable biological significance, more work upon it would be wise before we accept it.

\section{Density inversions in August 1950}

At all 'Sir Lancelot' stations on 8 August 1950 between numbers 35 and 4I (except 35), there was an apparent density inversion around 75-100 $\mathrm{m}$ depth (Table I) (cf. Spilhaus, Ehrlich \& Miller, I950). The apparent inversion

TABLE 1. DENSITY INVERSION IN SOUTHERN CELTIC SEA IN AUGUST 1950

(Minimum salinity and density in italics.)

\begin{tabular}{|c|c|c|c|c|c|c|c|c|}
\hline Depth (m) & 33 & 34 & 36 & 37 & 38 & 39 & 40 & $4 I$ \\
\hline & \multicolumn{8}{|c|}{ Temperature $\left({ }^{\circ} \mathrm{C}\right)$} \\
\hline 50 & II $\cdot 63$ & II 62 & 13.66 & 15.57 & II $\cdot 32$ & II $\cdot 02$ & 10.98 & $10 \cdot 82$ \\
\hline $\begin{array}{r}75 \\
100\end{array}$ & II. 52 & II. 56 & II. 65 & & & II $\cdot 02$ & $11 \cdot 00$ & $10 \cdot 82$ \\
\hline \multirow{3}{*}{ Bottom } & & II $\cdot 58$ & II $\cdot 63$ & II $\cdot 42$ & II $\cdot 28$ & II $\cdot 02$ & 10.99 & \\
\hline & II.5I & II $\cdot 58$ & II $\cdot 62$ & $\mathrm{II} \cdot 42$ & II $\cdot 28$ & II $\cdot O I$ & - & $10 \cdot 82$ \\
\hline & \multicolumn{8}{|c|}{ Salinity $(\%)$} \\
\hline $\begin{array}{l}50 \\
75\end{array}$ & 35.44 & $35 \cdot 48$ & $35 \cdot 52$ & $35 \cdot 44$ & 35.52 & $35.4 \mathrm{I}$ & $35 \cdot 44$ & $35 \cdot 38$ \\
\hline $\begin{array}{r}75 \\
\text { 100 }\end{array}$ & 35.50 & 35.52 & 35.55 & $35 \cdot 50$ & $35^{\circ}$ & 35.48 & 35.46 & $35 \cdot 39$ \\
\hline $\begin{array}{l}\text { I00 } \\
\text { Bottom }\end{array}$ & & 35.48 & 35.53 & & & 35.44 & 35.44 & 35.36 \\
\hline \multirow{2}{*}{ Decrease in salinity } & $\begin{array}{r}35.44 \\
0.06\end{array}$ & $\begin{array}{r}35.50 \\
0.04\end{array}$ & $\begin{array}{r}35.55 \\
0.02\end{array}$ & $\begin{array}{r}35.46 \\
0.09\end{array}$ & $\begin{array}{r}35.52 \\
0.06\end{array}$ & $\begin{array}{r}35.44 \\
0.04\end{array}$ & $\overline{0.02}$ & 0.03 \\
\hline & \multicolumn{8}{|c|}{ Density $\left(\sigma_{t}\right)$} \\
\hline 50 & 27.02 & 27.05 & $26 \cdot 68$ & $26 \cdot 20$ & $27 \cdot 14$ & $27 \cdot I I$ & $27 \cdot 14$ & $27 \cdot 12$ \\
\hline & 27.09 & 27.09 & 27 & 27. & & $27 \cdot 16$ & $27 \cdot 15$ & $27 \cdot 13$ \\
\hline 100 & - & $27 \cdot 06$ & 27.09 & $27 \cdot 14$ & & $27 \cdot 13$ & $27 \cdot 14$ & \\
\hline Bottom & $27 \cdot 04$ & 27.08 & $27 \cdot 11$ & & & & - & $27 \cdot 11$ \\
\hline Decrease ir & 0.05 & 0.03 & 0.01 & 0.07 & 0.05 & 0.03 & 0.01 & 0.02 \\
\hline Bot & II 8 & & 148 & & 130 & 125 & 100 & IIO \\
\hline Sounding & I 24 & 133.5 & $155^{\circ}$ & 146 & I37 & 134 & 108 & II5 \\
\hline
\end{tabular}


is due to changes in salinity rather than temperature. Although the variations in salinity are little greater than the titration error in Knudsen's method, the coherence of the data suggests that we must consider them seriously.

For a static system, the apparent inversion can be true only if we reject the principle of constant composition of sea salt. A dynamic explanation is more probable, namely, that the fast-moving water at thermocline level was associated with considerable water movement immediately beneath. This immediately subthermocline water had the properties of a projectile and so was able to maintain itself for some time above bottom water of slightly lower density.

\section{The 'Discovery II' section in May 1950}

The section over the slope between $48^{\circ} 18^{\prime} \mathrm{N} ., 7^{\circ} 30^{\prime} \mathrm{W}$. and $47^{\circ} 24^{\prime} \mathrm{N}$., $7^{\circ} 52^{\prime} \mathrm{W}$. has already been illustrated and discussed (Cooper, I952, fig. I4). To quote: 'Assuming only horizontal water movements, the density gradient would indicate a weak east-bound current, flowing along the edge of the slope, in agreement with the current system already deduced for the region by Helland-Hansen and Nansen; but since vertical currents and internal waves may also have played a part no firm conclusions are possible. At least it seems that the impoverished warm saline surface water is more likely to have come from the ocean to the south-west than from the Biscayan shelf to the south-east.'

TABLE 2. EVIDENCE FOR CLOCKWISE BOTTOM CURRENT IN SOUTHERN CELTIC SEA, APRIL-MAY, 1950

\begin{tabular}{|c|c|c|c|c|c|c|c|}
\hline $\begin{array}{ll}\text { Station } & . . \\
\text { Date } & . . \\
\text { Lat. } & . \\
\text { Long. } & . . \\
\text { Depth } & . .\end{array}$ & \multicolumn{3}{|c|}{$\begin{array}{l}\text { 'Sabella' I6 } \\
\text { I9 April } \\
49^{\circ} 30^{\prime} \mathrm{N} . \\
8^{\circ} 30^{\prime} \mathrm{W} . \\
140 \mathrm{~m}\end{array}$} & \multirow{2}{*}{$\begin{array}{c}\text { 19 April } \\
48^{\circ} 20^{\prime} \mathrm{N} . \\
6^{\circ} 06^{\prime} \mathrm{W} . \\
\\
\text { Temp. } \\
\text { computed } \\
\text { by applying } \\
\text { latitude } \\
\text { correction }\end{array}$} & \multicolumn{3}{|c|}{$\begin{array}{l}\text { 'Discovery' } 2654 \\
\text { II May } \\
48^{\circ} 20^{\prime} \mathrm{N} . \\
6^{\circ} 06^{\prime} \mathrm{W} . \\
\text { I24 m }\end{array}$} \\
\hline $\begin{array}{l}\text { Depth } \\
\text { sampled } \\
(\mathrm{m})\end{array}$ & $\begin{array}{c}\text { Temp. } \\
\left({ }^{\circ} \mathrm{C}\right)\end{array}$ & $\begin{array}{l}\text { Sal. } \\
(\%)\end{array}$ & $\underset{(\mu \text { g-atom/1.) }}{\text { Inorg. } \mathbf{P}}$ & & $\begin{array}{c}\text { Temp. } \\
\left({ }^{\circ} \mathrm{C}\right)\end{array}$ & $\begin{array}{l}\text { Sal. } \\
(\%)\end{array}$ & $\begin{array}{c}\text { Silicate-Si } \\
(\mu \mathrm{g} \text {-atom/l. })\end{array}$ \\
\hline $\begin{array}{r}50 \\
100\end{array}$ & 10.48 & $35 \cdot 44$ & 0.39 & $\begin{array}{l}\text { II.05 } \\
\text { II.05 }\end{array}$ & $\begin{array}{l}10.87 \\
10.85\end{array}$ & $\begin{array}{l}35 \cdot 44 \\
35 \cdot 43\end{array}$ & $\begin{array}{l}2 \cdot I \mathrm{I} \\
\mathrm{I} \cdot 97\end{array}$ \\
\hline 120 & 10.48 & $35 \cdot 44$ & 0.38 & . & - & & \\
\hline
\end{tabular}

The most striking feature of the section on the shelf (Figs. 3, I4) along the parallel $48^{\circ} 20^{\prime} \mathrm{N}$. in May was the cold core below $50 \mathrm{~m}$ at station 2654 (Table 2). The mean Celtic Sea latitude temperature for $48^{\circ} 20^{\prime} \mathrm{N}$. (Cooper, I960) for 3 weeks earlier was $\mathrm{II}^{\circ} 05^{\circ} \mathrm{C}$. There is no question but that this water was cold for the place and date. Intrusion as a submarine eagre from the south was impossible since the silicate content was only $2 \cdot 0 \mu \mathrm{g}$-atom $/ 1$. This cold core can have come only from the north or north-west. The 'Sir Lancelot' 
sections across the English Channel on 8 April show that such high salinity water could not have come from there. In the 'Sabella' line on I9 April along the parallel $49^{\circ} 30^{\prime} \mathrm{N}$. (Fig. I6), similar water is recognizable only at station I6 (Table 2).

The low phosphate at the bottom at 'Sabella' station I6 is also incompatible with an 'eagre' component, but the other properties suggest none the less that it must have approached station 16 from west-south-west or southwest.

The bottom configuration severely restricts the possibilities of what a bottom current may do. It is highly probable (Fig. I6) that the movement originated in an inflow over the indentation in the shelf at about $48^{\circ} 50^{\prime} \mathrm{N}$., $9^{\circ} 40^{\prime} \mathrm{W}$. (not as an eagre) and that its flow was controlled between the Cockburn, Jones and associated banks on the north-west and north and the Melville Knoll on the south. The Melville Knoll formed a fulcrum around which the current was compelled to turn. Its recognition at station 16 is so explained but, if the current had been streamlined, a greater influence might have been expected at station 15 .

We have seen that horizontal currents, like cascading water masses, may tend to break up into writhing boluses. When such a current system is examined by a grid of stations it is a matter of chance whether one samples the core of a bolus or the envelope of water drawn in to fill the constriction between two boluses in sequence. If the bottom current shown in Fig. I6 is accepted, then it is necessary to accept as well the bolus hypothesis for horizontal currents.

The current would seem to have passed close to the position $49^{\circ} \mathrm{N} ., 7^{\circ} \mathrm{W}$., turning right under the influence of the earth's rotation. Its farther southward passage had then to lie east of Parsons Bank.

The first station on this section, no. 2653, lay 20 miles west of Ushant and could give no evidence as to whether any current was flowing close into Ushant. The surface observation from line ro (Figs. 2, 3) on the following day at $48^{\circ} 26^{\prime}$ N., $5^{\circ} 16^{\prime}$ W., showed such a current at least weakly. The surface water had a density $\left(\sigma_{t}\right) 26 \cdot 84$.

Combining the evidence from the distribution of salinity between ' $D$ iscovery' stations 2657 and 2659 and the evidence from the bottom water at station 2654, we have a picture of a current of saline water setting parallel with the break of slope, i.e. towards east-south-east. That none of this water was entering the English Channel in May is confirmed by the total absence of high salinity water $(>35.5 \%$ ) on 'Sabella's' June section a few miles farther north.

An application of this deduction may be to the spawning habits of the hake. The Melville Knoll, according to Hickling (1935), is one of its largest spawning centres. He believes that the success of the spawning depends on the prevailing winds setting the young fish towards the east into shallower water. 
The probable set of the bottom current in 1950 suggests something rather different-a drift towards La Chapelle Bank where in June a rich and very characteristic euphausian type of plankton may occur in a narrow band parallel with the slope. The lead, slim though it is, seems worth further study.

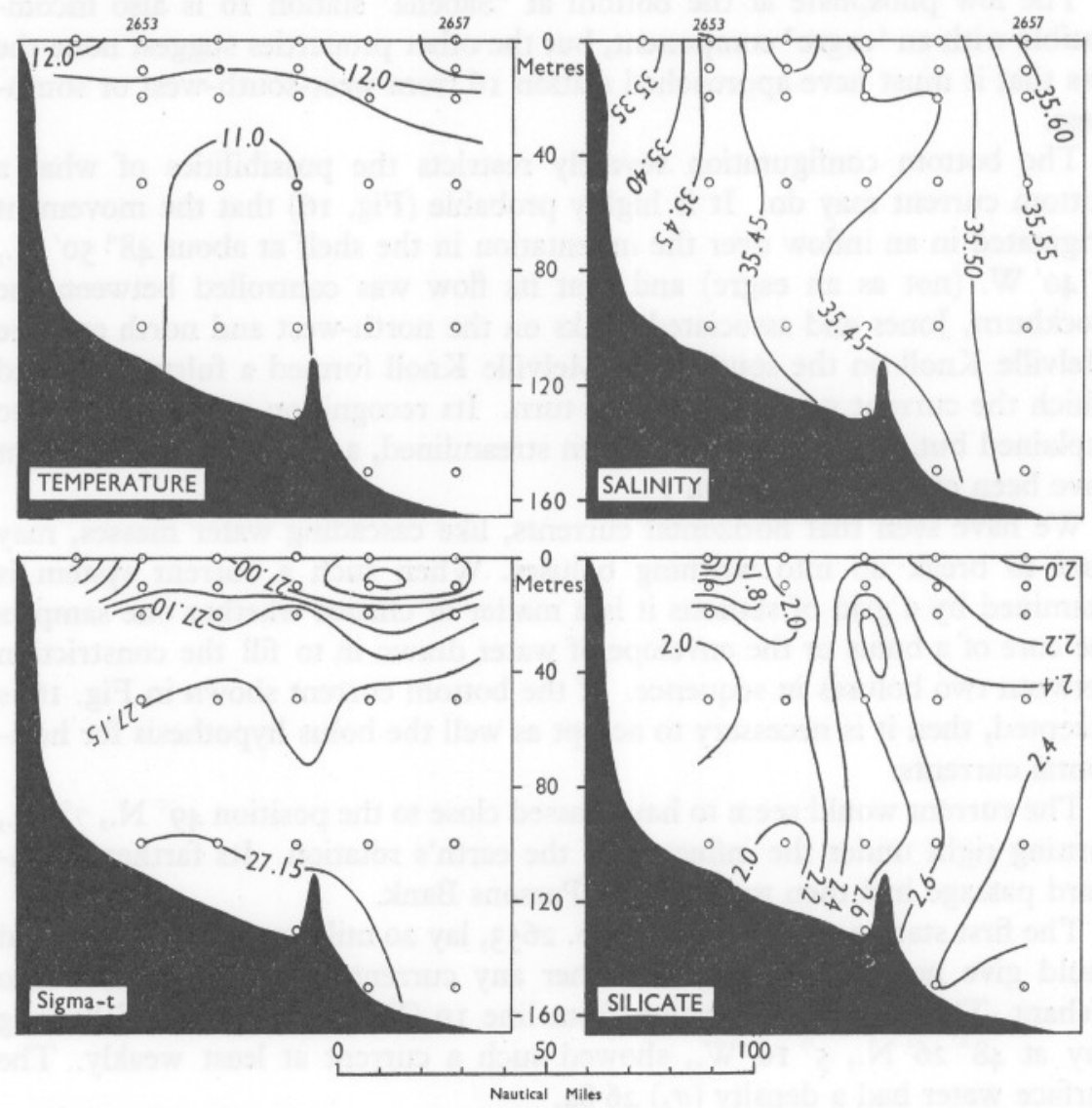

Fig. 14. Section along $48^{\circ} 20^{\prime}$ N. lat. worked by R.R.S. 'Discovery II' on II May 1950; temperature, ${ }^{\circ} \mathrm{C}$; salinity, $\%$; density, $\sigma_{t}$; and silicate, $\mu$ g-atom $/ 1$.

After the thermocline had developed strongly, water of the type found at 'Discovery' station 2655, but not necessarily from the position of that station, migrated north-westerly to be recognized at 'Sir Lancelot's' August station 40 (Fig. 17 and streamline $L$ in Fig. 12).

\section{The 'Sabella' section in fune 1950}

The course west of Ushant on I3 June I950 is shown in Fig. 3 (p. 179), and the temperature, salinity and density in Fig. I5 (left-hand panels). 

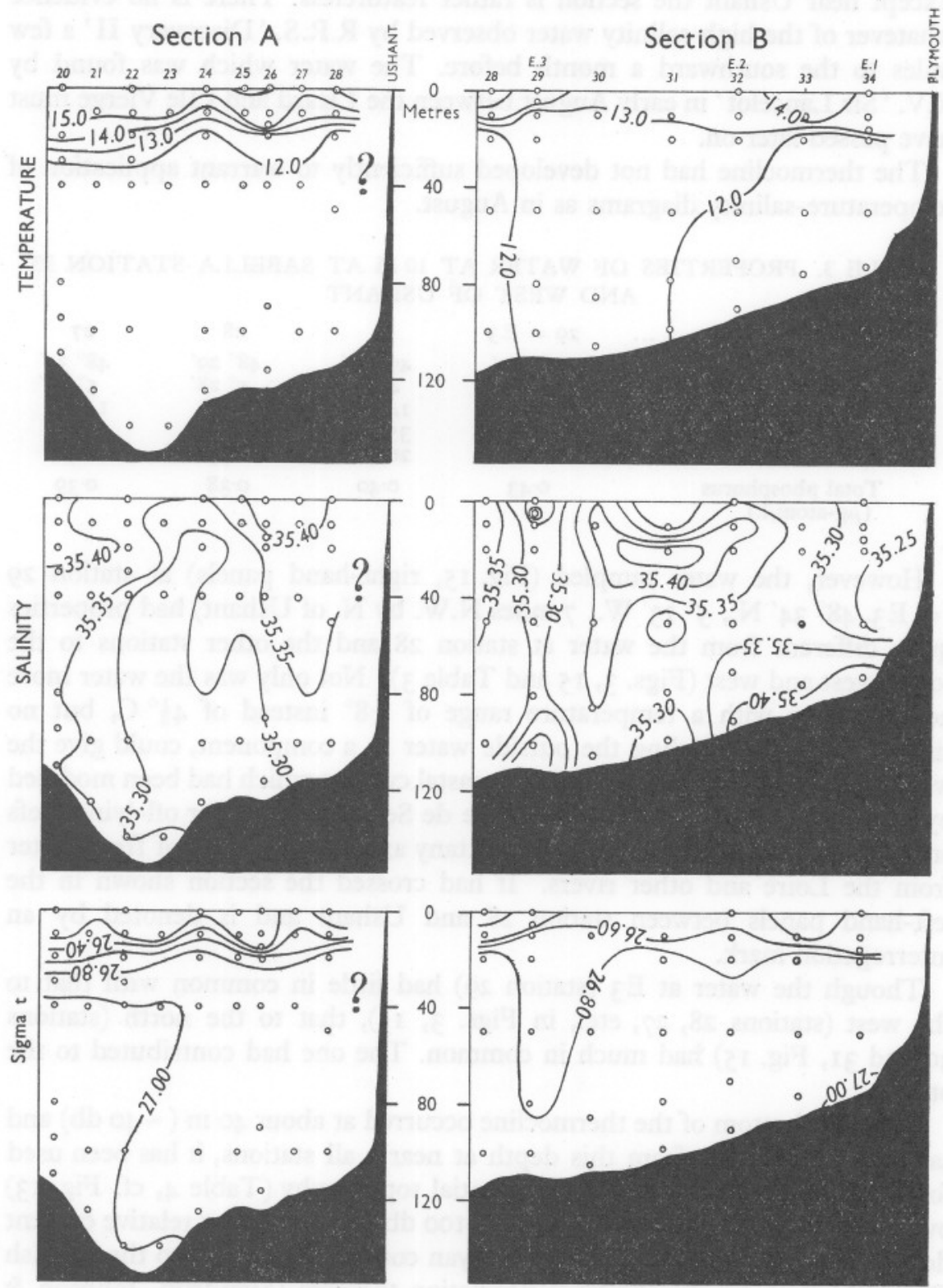

Fig. 15. Left-hand panels: 'Sabella' sections on I2-I4 June west of Ushant (see Fig. 3) for temperature, salinity and density; station 29 probably represents the water between station 28 and the Island of Ushant. Right-hand panels for the line from station 28 through station 29 (E) to Plymouth. 
Except near Ushant the section is rather featureless. There is no evidence whatever of the high-salinity water observed by R.R.S. 'Discovery II' a few miles to the southward a month before. The water which was found by R.V. 'Sir Lancelot' in early August between the Lizard and l'Ile Vierge must have passed later on.

The thermocline had not developed sufficiently to warrant application of temperature-salinity diagrams as in August.

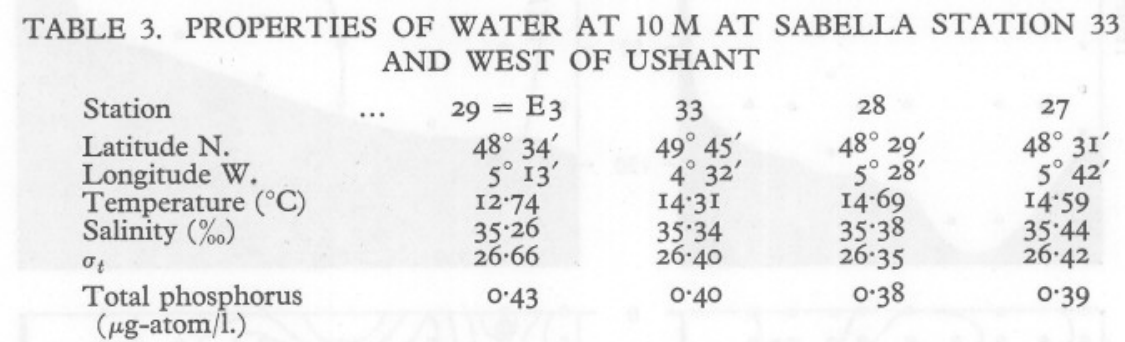

However, the water sampled (Fig. I5, right-hand panels) at station 29 ( $=\mathrm{E}_{3}, 48^{\circ} 34^{\prime} \mathrm{N}$., $5^{\circ} 13^{\prime}$ W., 7 miles N.W. by N. of Ushant) had properties quite different from the water at station 28 and the other stations to the south-west and west (Figs. 3, I5 and Table 3). Not only was the water more homogeneous with a temperature range of $\mathrm{I} \cdot 8^{\circ}$ instead of $4 \frac{1}{2}^{\circ} \mathrm{C}$, but no simple mixture, including the outside water as a component, could give the water found at $\mathrm{E}_{3}$. This was part of a coastal current which had been modified by turbulent passage over the Chaussée de Sein and the other off-lying reefs and islands along the west coast of Brittany and by admixture of fresh water from the Loire and other rivers. It had crossed the section shown in the left-hand panels between station 28 and Ushant and is denoted by an interrogation mark.

Though the water at $\mathrm{E}_{3}$ (station 29) had little in common with that to the west (stations 28, 27, etc., in Figs. 3, 15), that to the north (stations 30 and 3 I, Fig. I5) had much in common. The one had contributed to the other.

Since the bottom of the thermocline occurred at about $40 \mathrm{~m}(\sim 40 \mathrm{db})$ and samples were drawn from this depth at nearly all stations, it has been used for drawing charts of relative geopotential topography (Table 4, cf. Fig. 13) over the whole area. That for 40 against $100 \mathrm{db}$ shows a strong relative current flowing close to Ushant from the Biscayan coast of Brittany into the English Channel. Both by the Bjerknes circulation theorem (Sverdrup, Johnson \& Fleming, 1942) and by Harvey's (1929) simple derivation, the current at $40 \mathrm{~m}$ was not less than 4 miles per day.

There is little doubt that this represents a northward moving coastal mid-water current, strongest at $40 \mathrm{~m}$, and not a reverse current strongest at 
the bottom. The chart for the current at the surface relative to that at $40 \mathrm{~m}$ indicates either a surface current towards the south or a current at $40 \mathrm{~m}$ towards the north. Here, to reconcile the two charts, the second explanation must be true.

Dissection of geopotential anomalies at stations 29 to 26 (Table 4) shows that the components of relative current were small within the $20-40 \mathrm{~m}$ layer and were largely confined to the layers above $20 \mathrm{~m}$ and below $40 \mathrm{~m}$, as required by the theory. The maximum strength of the north-flowing current therefore lay somewhere in the $20-40 \mathrm{~m}$ stratum.

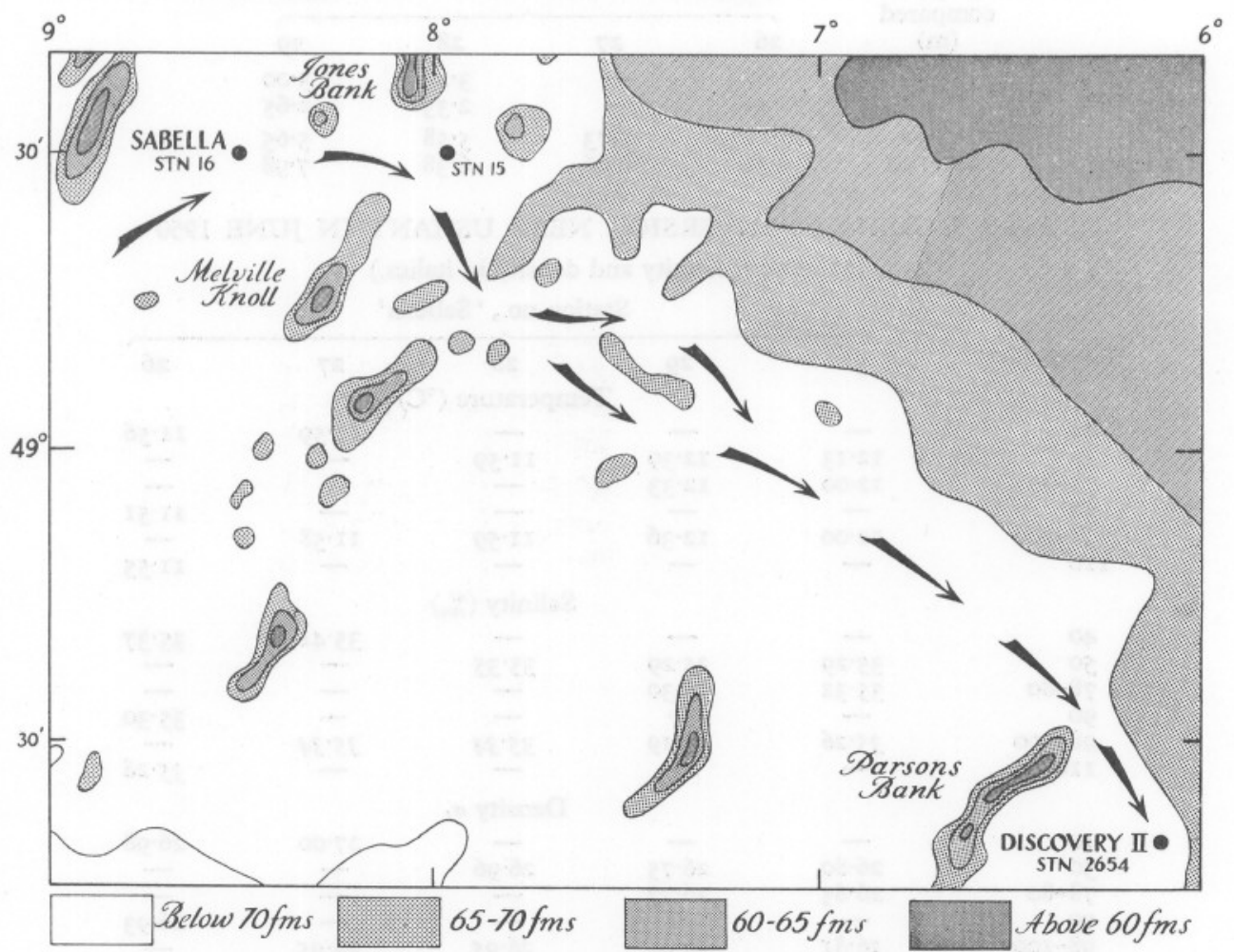

Fig. 16. Probable course of a bottom current in April-May 1950.

Much of the water entering the English Channel at the time had temperature between 12.3 and $12.5^{\circ} \mathrm{C}$, salinity about $35.3 \%$, density $\left(\sigma_{t}\right)$ about 26.7-26.8, total phosphorus $0.45 \mu \mathrm{g}$-atom/1. This warm, nutrient-poor bottom water was found north of Ushant for more than 30 miles. The situation was closely similar to that found north of west Cornwall.

The inflexion in geopotential farther west at station 24 in all curves involving the surface was not shown in the curve for 40 against $100 \mathrm{db}$. It was due to a shallow (0-20 m depth) current of cold, relatively low-salinity water, 
but whether this was an eddy from the Ushant corner current or whether it came from the north cannot be decided.

This picture is relative. The whole of the water as far west as $7^{\circ} 45^{\prime} \mathrm{W}$. was moving slowly northward, a movement which needs to be superimposed upon the relative corner currents at Ushant.

TABLE 4. ANOMALIES OF GEOPOTENTIAL WEST OF USHANT, JUNE 1950, DYNAMIC CENTIMETRES

$\begin{array}{ccccc}\begin{array}{c}\text { Depths } \\ \text { compared } \\ \text { (m) }\end{array} & \begin{array}{l}\text { West } \\ 26\end{array} & 27 & 28 & \text { Station } \\ \text { O-20 } & 3.67 & - & 3.25 & 29 \\ 20-40 & 2.45 & - & 2.33 & 2.65 \\ 0-40 & 6.12 & 5.73 & 5.58 & 5.65 \\ 40-100 & 6.71 & 6.66 & 6.38 & 7.98\end{array}$

TABLE 5. DENSITY INVERSION NEAR USHANT IN JUNE 1950 (Minimum salinity and density in italics.)

\begin{tabular}{|c|c|c|c|c|c|}
\hline \multirow[b]{2}{*}{ Depth (m) } & \multicolumn{5}{|c|}{ Station no., 'Sabella' } \\
\hline & $3 \mathrm{I}$ & 29 & $\begin{array}{c}28 \\
\text { perature }\end{array}$ & 27 & 26 \\
\hline 40 & - & - & - & II 59 & II. 56 \\
\hline 50 & I2.13 & 12.39 & II 59 & - & - \\
\hline $78-80$ & 12.00 & 12.33 & - & - & - \\
\hline & $\overline{12.00}$ & $\overline{12 \cdot 36}$ & $\overline{I I} \cdot 59$ & $\overline{I I} \cdot 58$ & II.5I \\
\hline \multirow[t]{2}{*}{$\begin{array}{l}\text { II } 6 \\
\text { I }\end{array}$} & 12 & - & -79 & - & II. 55 \\
\hline & \multicolumn{5}{|c|}{ Salinity $(\%)$} \\
\hline 40 & - & - & - & $35 \cdot 4 \mathrm{I}$ & $35 \cdot 37$ \\
\hline & 35.29 & 35.29 & $35 \cdot 35$ & 二 & \\
\hline $\begin{array}{l}78-80 \\
90\end{array}$ & $35 \cdot 32$ & $35 \cdot 30$ & $\bar{z}$ & 二 & $\overline{35 \cdot 3}$ \\
\hline $98-100$ & $35 \cdot 26$ & $35 \cdot 19$ & $35 \cdot 34$ & $35 \cdot 34$ & \\
\hline & & & & & $35 \cdot 28$ \\
\hline & \multicolumn{5}{|c|}{ Density $\sigma_{t}$} \\
\hline & $\overline{250}$ & $\bar{c}$ & - & $27 \cdot 00$ & $26 \cdot 98$ \\
\hline & $26 \cdot 80$ & $26 \cdot 75$ & $26 \cdot 96$ & & \\
\hline $78-80$ & $26 \cdot 85$ & $26 \cdot 77$ & - & - & \\
\hline $\begin{array}{l}90 \\
98-100\end{array}$ & $\overline{26 \cdot 8 I}$ & $\overline{26 \cdot 68}$ & $2 \overline{26.05}$ & $2 \overline{26.05}$ & 26.93 \\
\hline $\begin{array}{l}98-100 \\
\text { I16 }\end{array}$ & - & - & $20-93$ & 2095 & $26 \cdot 9$ \\
\hline Sounding & I03 & I IO & II 5 & II9 & 124 \\
\hline
\end{tabular}

No water from westward of the meridian $5^{\circ} 30^{\prime} \mathrm{W}$., and below $30 \mathrm{~m}$ in depth had entered the English Channel. There is some evidence that a little of the surface water of the kind found in the water westward of Ushant (stations 28-26) had reached station 33 (Figs. 3, I5) (Lizard Point 29 miles $209^{\circ}$ ) on the English side of the Channel. Apart from this no water from west of $5^{\circ} 30^{\prime} \mathrm{W}$. crossed the Plymouth-Ushant line, a situation very different from that found in August. 
In August we had evidence for a density inversion beneath the water moving fastest, so also have we in June (Table 5). On this occasion the fast-moving water and apparent density inversions were both grouped around Ushant. A similar explanation, no doubt, applies.

\section{The sequence of events in the summer of 1950}

The prevailing winds of this sea area are from the south-west and west. Such winds will tend to initiate surface currents towards the east and southeast. Wind-induced currents, at greater depths will tend, according to the theory of the Ekman spiral, to set still farther to the south.

Under these conditions there will be no tendency for the wind to set homogeneous water from south of $48^{\circ} 20^{\prime} \mathrm{N}$. into the English Channel. This agrees with the findings by R.R.S. 'Discovery II' in May.

The same prevailing winds will tend to initiate the same kind of currents in homogeneous water at any time of year, whatever the water temperature, so that these winds should never set water from west of Ushant into the English Channel (cf. Cooper, I960). Under these conditions recruitment of water into the Channel from the west should be from north of $49^{\circ} \mathrm{N}$. lat.

As soon as the thermocline begins to form, the wind will cease to influence the direction of movement of the deeper water. This will tend to move solely in accordance with the distribution of mass over the whole of the Celtic Sea, its bounding continental slope and the English, Bristol and Irish Channels.

As an empirical finding we can say that as the summer advanced the direction of movement of the deeper water in 1950 changed. The north-easterly movement first appeared in June as a coastal current around Ushant from the west coast to the north coast of Brittany.

As the thermocline strengthened, the site of the current entering the English Channel moved westwards. Water bound towards the English Channel was then confined to a thermocline layer about $20 \mathrm{~m}$ thick and crossing the parallel of latitude $48^{\circ} 20^{\prime} \mathrm{N}$. between $5^{\circ} 35^{\prime} \mathrm{W}$. and $7^{\circ} 00^{\prime} \mathrm{W}$. That part bound for the English Channel east of the Lizard headland was restricted to the range of longitude $5^{\circ} 35^{\prime}-6^{\circ} 00^{\prime} \mathrm{W}$. This current impinged on the north-western corner of Ushant.

At any time of year, heavy rainfall over western France and consequent river outflow to the sea will lead to a strong coastal current around Ushant. This will over-ride or supplement the circulation arising from the heat balance in the water to the westward and northward.

This reconstruction needs confirmation. It will be difficult to extract from our earlier records since our standard stations are too far apart. It would not have been possible to deduce this account if we had had data only from 'Sir Lancelot' August stations no. 25 and 34 and from 'Sabella' June stations 29 and 23, equivalent to international stations $\mathrm{E}_{3}$ and $\mathrm{E}_{4}$. 
The influence of these events on the English Channel as a whole and comparison with other years (Matthews, Lumby and Harvey) will be deferred. Preliminary comparison with the work of Dietrich (1950) has already been made. Further comparison is best achieved not by argument here but by seeking more measurements.

A comparison with the distribution of biological indicators is also deferred but mention may be made of the close parallel with Russell's (1935) findings. In his fig. 4 he sets out the arrival of south-western water off Plymouth in mid-August, 1930, I931, 1932, in July 1933 and September 1934.

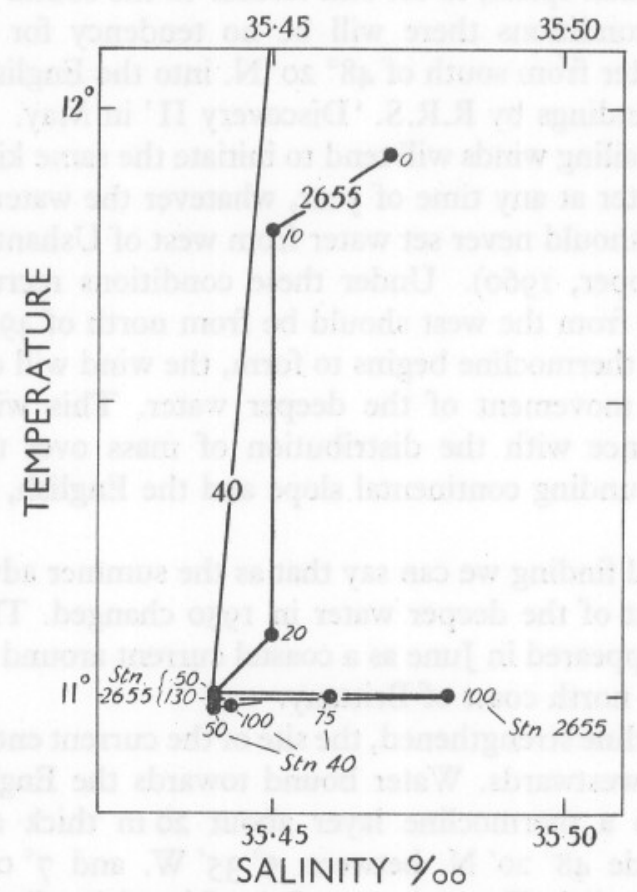

Fig. 17. Temperature-salinity diagrams for the water at 'Discovery' station 2655 ( $48^{\circ} 20^{\prime}$ ' N., $6^{\circ} 34^{\prime}$ W. on II May) and ' $S$ ir Lancelot' station 40 ( $49^{\circ} 02^{\prime}$ N., $6^{\circ} 52^{\prime}$ W. on 8 August I950); streamline $L$. To conform with the other streamlines transport to the north must have occurred mostly in the month before the August observation.

\section{THE PARTITION OF PHOSPHATE}

For many years in the English Channel near Plymouth inorganic phosphate at the winter maximum has averaged about $0.45 \mu \mathrm{g}$-atom $/ 1$., three-quarters of that available in the Bay of Biscay from which by a more or less direct route the water of the English Channel is recruited. It has long been a problem as to how $0.15 \mu \mathrm{g}$-atom $/ 1$. of inorganic phosphate or so is permanently removed from the water. 
The present study provides the answer for about half of this. In I950 we hoped that total phosphorus would prove a more nearly conservative property than inorganic phosphate; it also has the advantage of not requiring analyses to be made at sea. It has not proved conservative, so that analysis of total phosphorus has lost favour. Samples from 10,20 and $50 \mathrm{~m}$ and greater depths were sampled by R.V. 'Sir Lancelot' on the cruise of August I950 and analysed at the Plymouth Laboratory by Harvey's methods by Mr F. A. J. Armstrong.

Due to the problems of particulate distribution of phosphorus in living organisms and in detritus (seston) (cf. Cooper, 1948, for the parallel problem with iron), analyses of total phosphorus are less reproducible than those of inorganic phosphate. None the less, the August 1950 analyses are sufficiently precise to make my point.

First, let us consider all the analyses of total phosphorus at stations 30-34 between which at thermocline level water was entering the western English Channel. The mean of the eighteen analyses of bottom water below the thermocline is at $\mathrm{II} .67 \pm$ (S.D.) $0.09^{\circ} \mathrm{C}$ and $0.62 \pm$ (S.D.) $0.04 \mu \mathrm{g}$-atom/1. of total phosphorus. This is taken as a measure of the winter stock of total phosphorus available to enter the Channel. It may be somewhat lower than the average.

There is another cluster of nine analyses on the warm upper water with mean at $17.75 \pm$ (s.D.) $0.20^{\circ} \mathrm{C}$ and $0.305 \pm 0.02 \mu$ g-atom $/ 1$. total phosphorus. The straight line which joins the two centres of gravity leaves three analyses within the thermocline about $0.02 \mu \mathrm{g}$-atom $/ 1$. to the right.

This straight line has been used to estimate what the total phosphorus content in the deeper water at stations $25-18$ and $45-43$ should have been if it had suffered no change during passage from the thermocline at latitude $48^{\circ} 20^{\prime} \mathrm{N}$. to the observed position (Table 6 , col. 3 ). In the next column (col. 4) is given the content of total phosphorus observed. Column 5, representing the loss by thermocline partition, is the difference between $0.62 \mu \mathrm{g}$-atom $/ 1$. and the computed value in col. 3 .

At the stations near Ushant (25-23) where the time of travel was short and there was no opportunity for further partition, the computed and observed values agree well. The loss unaccounted for is small. As, however, we go northward and the travel time of the water becomes greater, the loss in total phosphorus unaccounted for becomes greater. A calculation in terms of density instead of temperature gives a similar result.

The physical partition occurring at the thermocline at $48^{\circ} 20^{\prime} \mathrm{N}$. therefore accounts for about one-half of the loss regularly observed off Plymouth. The fate of the other half will be considered when the physical and chemical oceanography of the English Channel in 1950 comes to be published. 
TABLE 6. LOSS OF TOTAL PHOSPHORUS ON PASSAGE BETWEEN THE BAY OF BISCAY AND THE WESTERN ENGLISH CHANNEL

Total phosphorus ( $\mu \mathrm{g}$-atom $/ 1$.

\begin{tabular}{|c|c|c|c|c|c|}
\hline \multirow[b]{2}{*}{$\begin{array}{l}\text { Station, } \\
\text { 'Sir } \\
\text { Lancelot' }\end{array}$} & \multirow[b]{2}{*}{$\begin{array}{c}\text { Depth } \\
\text { (m) }\end{array}$} & \multirow[b]{2}{*}{$\begin{array}{l}\text { Computed } \\
\text { graphically }\end{array}$} & \multirow[b]{2}{*}{ Observed } & \multicolumn{2}{|c|}{ Loss of $\Sigma P$} \\
\hline & & & & $\begin{array}{l}\text { By } \\
\text { thermocline } \\
\text { partition }\end{array}$ & $\begin{array}{l}\text { Unaccounted } \\
\text { for }\end{array}$ \\
\hline 25 & $\begin{array}{r}50 \\
75 \\
100\end{array}$ & $\begin{array}{l}0.55 \\
0.57 \\
0.59\end{array}$ & $\begin{array}{l}0.53 \\
0.54 \\
0.56\end{array}$ & $\begin{array}{l}0.07 \\
0.05 \\
0.03\end{array}$ & $\begin{array}{l}0.02 \\
0.03 \\
0.03\end{array}$ \\
\hline 24 & $\begin{array}{l}50 \\
90\end{array}$ & $\begin{array}{l}0.52 \\
0.53\end{array}$ & $\begin{array}{l}0.57 \\
0.53\end{array}$ & $\begin{array}{l}0.10 \\
0.09\end{array}$ & $\begin{array}{r}-0.05 \\
\mathrm{Nil}\end{array}$ \\
\hline 23 & $\begin{array}{l}50 \\
88\end{array}$ & $\begin{array}{l}0.49 \\
0.50\end{array}$ & $\begin{array}{l}0.47 \\
0.50\end{array}$ & $\begin{array}{l}0.13 \\
0.12\end{array}$ & $\begin{array}{l}0 \cdot 02 \\
\mathrm{Nil}\end{array}$ \\
\hline 22 & $\begin{array}{l}50 \\
92\end{array}$ & $\begin{array}{l}0.51 \\
0.53\end{array}$ & $\begin{array}{l}0.46 \\
0.51\end{array}$ & $\begin{array}{l}0.11 \\
0.09\end{array}$ & $\begin{array}{l}0.05 \\
0.02\end{array}$ \\
\hline 21 & $\begin{array}{l}50 \\
94\end{array}$ & $\begin{array}{l}0.51 \\
0.53\end{array}$ & $\begin{array}{l}0.46 \\
0.50\end{array}$ & $\begin{array}{l}0.11 \\
0.09\end{array}$ & $\begin{array}{l}0.05 \\
0.03\end{array}$ \\
\hline 20 & $\begin{array}{l}50 \\
87\end{array}$ & $\begin{array}{l}0.53 \\
0.54\end{array}$ & $\begin{array}{l}0.46 \\
0.50\end{array}$ & $\begin{array}{l}0.09 \\
0.08\end{array}$ & $\begin{array}{l}0.07 \\
0.04\end{array}$ \\
\hline 19 & $\begin{array}{l}50 \\
80\end{array}$ & $\begin{array}{l}0.56 \\
0.56\end{array}$ & $\begin{array}{l}0.43 \\
0.47\end{array}$ & $\begin{array}{l}0.06 \\
0.06\end{array}$ & $\begin{array}{l}0.13 \\
0.09\end{array}$ \\
\hline I8 & $\begin{array}{l}50 \\
73\end{array}$ & $\begin{array}{l}0.58 \\
0.58\end{array}$ & $\begin{array}{l}0.48 \\
0.49\end{array}$ & $\begin{array}{l}0.04 \\
0.04\end{array}$ & $\begin{array}{l}0.10 \\
0.09\end{array}$ \\
\hline 46 & - & - & No analyses & - & - \\
\hline 45 & $\begin{array}{l}50 \\
70\end{array}$ & $\begin{array}{l}0.60 \\
0.60\end{array}$ & $\begin{array}{l}0.52 \\
0.54\end{array}$ & $\begin{array}{l}0.02 \\
0.02\end{array}$ & $\begin{array}{l}0.08 \\
0.06\end{array}$ \\
\hline 44 & $\begin{array}{l}50 \\
80\end{array}$ & $\begin{array}{l}0.59 \\
0.60\end{array}$ & $\begin{array}{l}0.49 \\
0.54\end{array}$ & $\begin{array}{l}0.03 \\
0.02\end{array}$ & $\begin{array}{l}0.10 \\
0.06\end{array}$ \\
\hline 43 & 85 & 0.59 & 0.52 & 0.03 & 0.07 \\
\hline
\end{tabular}

This paper has been difficult to write and may prove even more difficult to read. None the less it is a foretaste of what may come apace when the increasing application of the salinometer makes it possible to unravel certain movements of stratified waters in great detail. Biologists need such information but, confronted with it, may recoil in horror. Physical oceanographers may therefore need to consider how they can systematize the extraction and presentation of the desired information. Probably diagrams, such as Figs. 4-7 presented here solely to illustrate a worked example, should be pigeon-holed when they have served their turn and publication restricted to diagrams such as Figs. 9 and 12 and the minimum of textual description. It may be necessary to develop a block diagram form of presentation on the lines of Fig. 8. The possibility of criticism should have vanished so that conclusions would need to be taken on trust. Comment will be appreciated.

The author is greatly indebted to Mr G. A. W. Battin for his excellent illustrations. Without these the paper would have been even more turgid. 
He is also grateful to Lt.-Cdr. C. A. Hoodless, D.S.C., R.N.R., then master of R.V. 'Sabella', and his crew for much help in I950; also to Mr David Vaux of the Lowestoft Laboratory for making data and diagrams of 'Sir Lancelot's' cruises quickly available.

\section{SUMMARY}

The currents around a prominent headland, the island of Ushant between the Bay of Biscay and the English Channel, are discussed.

The flow in the spring of 1928 has been re-examined. Run off from the Loire watershed reached Ushant in March. North of Ushant it spread out before passing up the English Channel on the French side. Some of this water spread northwards from Guernsey towards England and reached the neighbourhood of Plymouth by mid-April and the Seven Stones Light Vessel a fortnight later, i.e. the flow was cyclonic within the western bight of the Channel and took about to weeks to travel from Ushant to Land's End at a rate over the ground of 3 miles a day.

In May 1950 currents in the southern Celtic Sea were setting east-south-east parallel with the slope. No water there was moving towards the English Channel in May and June. The bearing of this result on successful hake spawning is briefly discussed.

In June 1950 a narrow coastal current, strongest at about $40 \mathrm{~m}$ depth, was setting round Ushant and fanning out in the English Channel north of Brittany; however, no water from west of $5^{\circ} 30^{\prime} \mathrm{W}$. long. was then entering the Channel near Ushant.

Once the thermocline had become well established the pattern of currents changed completely, as shown by closely spaced stations worked by R.V. 'Sir Lancelot' in August. The salinities have the greatest precision attainable by the Knudsen technique and have made possible a detailed study of current streamlines. It is assumed that properties beneath the thermocline were conservative. Using temperature-salinity diagrams, a sheaf of streamlines has been constructed which, except for I salinity out of about I 20 which are relevant, form a completely coherent pattern. There was a large recruitment of water into the mouth of the English Channel across the parallel $48^{\circ} 20^{\prime} . \mathrm{N}$. between $5^{\circ} 35^{\prime} \mathrm{W}$. and $7^{\circ} 00^{\prime} \mathrm{W}$., and this recruitment was from a layer at thermocline level about $20 \mathrm{~m}$ thick. The deeper water followed the streamlines, $A-F$ and $H$ in Fig. I2. These thermocline waters were undergoing a partition, the shallower waters setting to the right of the deeper and sinking while so doing (streamlines $G, P$ and $Q$ ). This mechanism explains in part the excessive warming up of the south-western English Channel to which Dietrich drew attention. There is an apparent conflict with some of the German conclusions which will need further sea work to resolve.

This mechanism accounts for about one-half of the impoverishment in 
phosphate observed as between the Bay of Biscay and the winter maximum in the English Channel.

Slight density inversions occurred in June and August.

In order that the conclusions may be fairly criticized much intricate scaffolding has had to be presented. This may have obscured the results of interest to biologists.

\section{REFERENCES}

CARRUTHERS, J. N. 1927. Investigations upon the water movements in the English Channel. Summer, 1924. F. mar. biol. Ass. U.K., Vol. 14, pp. 685-721.

CONSEIL PERMANENT INTERNATIONAL POUR L'EXPLORATION DE LA MER, I929a. Bull. hydrogr. pour l'année I928, II5 pp. Copenhagen.

- 1929b. Rapport Atlantique 1928. Rapp. Cons. Explor. Mer, Vol. 62, I03 pp. I954. Bull. hydrogr. pour l'année I950. II4 pp. Copenhagen.

COOPER, L. H. N., 1948. The distribution of iron in the waters of the western English Channel. F. mar. biol. Ass. U.K., Vol. 27, pp. 279-313 and 314-321.

- I952. The physical and chemical oceanography of the waters bathing the continental slope of the Celtic Sea. F. mar. biol. Ass. U.K., Vol. 30, pp. 465-5Io.

— 1957. Death of a Channel herring fishery. New Scientist, May 2.

- 1960. Some theorems and procedures in shallow-water oceanography applied to the Celtic Sea. F. mar. biol. Ass. U.K., Vol. 39, pp. 155-171.

DIETRICH, G., I950. Die anomale Jahresschwankung des Wärmeinhalts im Englischen Kanal, ihre Ursachen und Auswirkungen. Dtsch. hydrogr. Z., Bd. 3, pp. 184-201.

- 1951. Influences of tidal streams on oceanographic and climatic conditions in the sea as exemplified by the English Channel. Nature, Lond., Vol. I68, p. 8.

Ekman, V. W., I905. On the influence of the earth's rotation on ocean currents. Ark. Mat. Astr. Fys., Bd. 2, No. II, 52 pp.

HANSEN, W., 1950. Gezeiten im Englischen Kanal. Dtsch. hydrog. Z., Bd. 3, pp. I6983.

HaRvey, H. W., 1929. Hydrodynamics of the waters south east of Ireland. F. Cons. int. Explor. Mer, Vol. 4, pp. 80-92.

HICKLING, C. F., 1935. The Hake and the Hake Fishery. Buckland Lectures for 1934. London: Arnold.

Poole, H. H. \& AtkIns, W. R. G., 1929. Photo-electric measurements of submarine illumination throughout the year. F. mar. biol. Ass. U.K., Vol. 16, pp. 297-324.

RUSSELL, F. S., I935. On the value of certain plankton animals as indicators of water movements in the English Channel and North Sea. F. mar. biol. Ass. U.K., Vol. 20, pp. 309-32.

Spilhaus, A. F., Ehrlich, A. \& Miller, A. R., 1950. Hydrostatic instability in the sea. Trans. Amer. geophys. Un., Vol. 31, pp. 213-5.

SverdRup, H. U., Johnson, M. W. \& Fleming, R. H., I942. The Oceans. Their Physics, Chemistry and General Biology. 1087 pp. New York. 